CHAMBERS, $R$.

Seasonal...
SEASONAL
DIMENSIONS TO
RURAL POVERTY
Edited by

Robert Chambers, Richard Longhurst and Arnold Pacey

SNM -

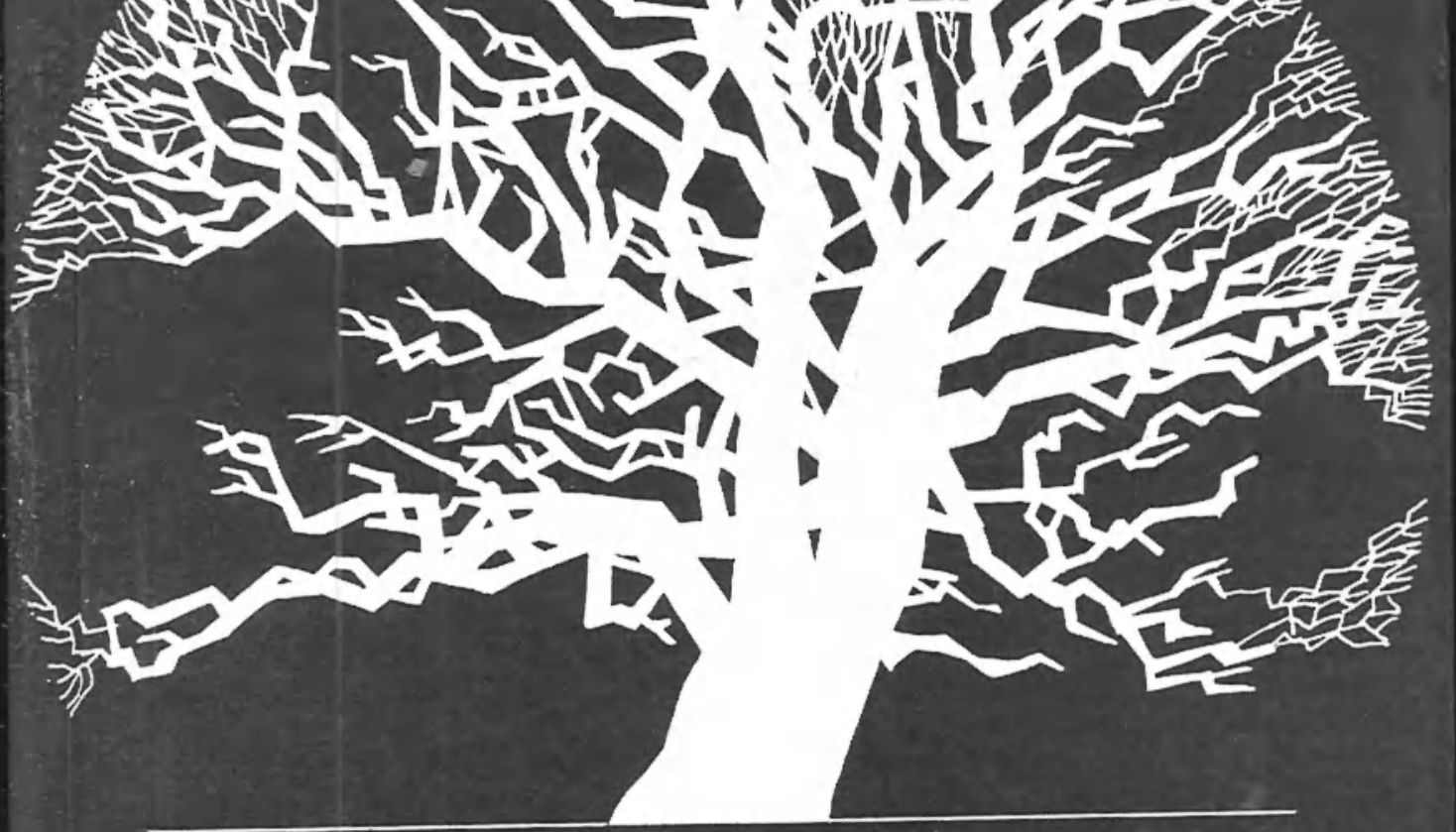




\title{
SEASONAL DIMENSIONS TO RURAL POVERTY
}

\author{
EDITED BY \\ ROBERT CHAMBERS, RICHARD LONGHURST \\ ARNOLD PACEY
}

Frances Pinter (Publishers) Ltd 
(C) Institute of Development Studies 1981

Published in Great Britain in 1981 by

Frances Pinter (Publishers) Limited

5 Dryden Street, London WC2E 9NW

British Library Cataloging in Publication Data

Seasonal dimensions to rural poverty.

I. Seasonal variations (Economics)-Tropics-

Case studies

I. Chambers, Report, 1932- II. Longhurst,

Richard III. Pacey, Arnold

330.9173'4 HC79.S/

ISBN 0-86187-334-3

Printed by SRP Ltd, Exeter 
To every thing there is a season, and a time to every purpose under the heaven; a time to be born, and a time to die; a time to plant, and a time to pluck up that which is planted

Eccles. $3: 1-2$ 


\section{CONTENTS}

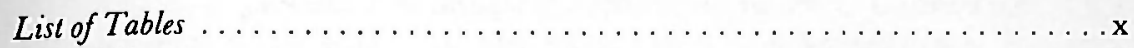

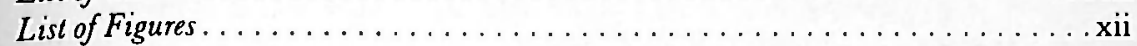

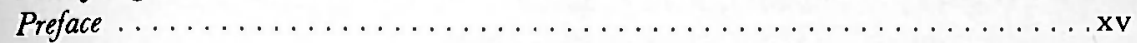

INTRODUCTION, Robert Chambers . . . . . . . . . . . . .

1. CLIMATIC SEASONALITY IN THE TROPICS $\ldots \ldots \ldots \ldots \ldots 9$

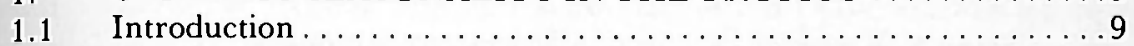

1.2 The Nature of Climatic Seasonality, R.P.D. Walsh . . . . . . . . 11

1.3 Case-Studies . . . . . . . . . . . . . . . . . . . . . . . 21

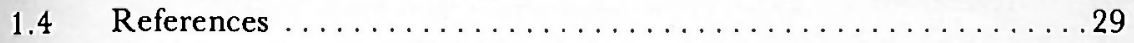

2. SEASONAL ENERGY RELATIONSHIPS AND FOOD . . . . . 30

2.1 Seasonality and Labour in the Rural Energy Balance,

Tim Bayliss-Smith . . . . . . . . . . . . . . . . . . . . . . . . 30

2.2 Food Consumption in Relation to Labour Output,

Margaret Haswell . . . . . . . . . . . . . . . . . . . 38

2.3 Nutrition and Disease in Machakos District, Kenya

Simeon $R$. Onchere and $R$. Slooff . . . . . . . . . . . . . . 41

2.4 Seasonal Aspects of Nutrition, Richard Longhurst and

Philip Payne . . . . . . . . . . . . . . . . . . . . . . 45

2.5 Agriculture and Nutrition in Matlab Thana, Bangladesh,

A.K.M. Alauddin Chowdhury, Sandra L. Huffman and Lincoln

C. Chen ... . . . . . . . . . . . . . . . . . . . . . . . . . . . . 52

2.6 Energy Needs and Technology, Arnold Pacey . . . . . . . . . . . 61

$2.7 \quad$ References ............................63

3. EGONOMIC RELATIONSHIPS AND THE

SEASONAL USE OF LABOUR . . . . . . . . . . . . . . . .67

3.1 Seasonality in the Rural Economy (of Tropical Africa),

Philip Raikes ........................... 67

3.2 A Case-Study in Food Production, Sale and Distribution, Emmy $B$. Simmons . ........................ . 73

3.3 Labour and Subsistence in a Pastoral Economy, Jeremy Swift .............................. 80

3.4 The Seasonality of Prices and Wages in Bangladesh, Rafiqul Huda Chaudhury.......................87

3.5 Seasonal Patterns of Agricultural Employment in Bangladesh, Edward J. Clay. . . . . . . . . . . . . . . . . . . . . 92 


\section{Contents}

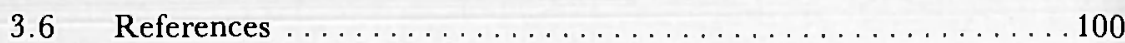

4. THE SEASONAL ECOLOGY OF DISEASE . . . . . . . . . 102

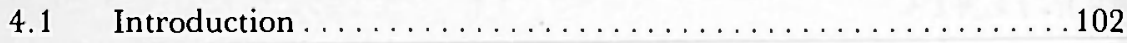

4.2 Diarrhoeal Diseases, B. S. Drasar, A. M. Tomkins and

R. G. Feachem . . . . . . . . . . . . . . . . . . . . . . 102

4.3 Diarrhoeal Diseases: Rotavirus Infection in Children,

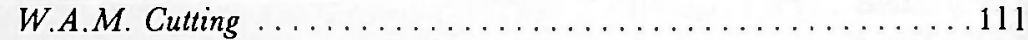

4.4 Respiratory Diseases, R.N.P. Sutton . . . . . . . . . . . . . . . . 112

4.5 Infectious Skin Diseases, Michael J. Porter. . . . . . . . . . . . 114

4.6 Insect-Borne Diseases: Malaria, R. S. Bray ............... 116

4.7 Insect-Borne Diseases: Filarial Infections and Kala-Azar,

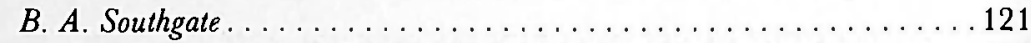

$4.8 \quad$ Guinea-Worm Infection, $R$. Muller ................. 125

4.9 Seasonal Variables in Infective Disease: A Summary,

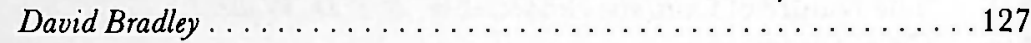

$4.1 \quad$ References ................................ 131

5. SEASONAL PATTERNS IN BIRTHS AND DEATHS . . . . . 135

5.1 Causes of Seasonal Fluctuation in Vital Events, Tim Dyson

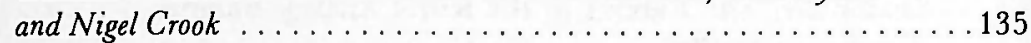

5.2 Data on Seasonality of Births and Deaths, Nigel Crook and Tim Dyson . . . . . . . . . . . . . . . . . . . . . . 141

5.3 Seasonal Patterns of Vital Events in Matlab Thana,

Bangladesh, Stan Becker and M. A. Sardar . . . . . . . . . . 149

5.4 Seasonality of Births in the Solomon Islands, Sheila Macrae . . . . . . 154

5.5 Births, Work and Nutrition in Tamil Nadu, India,

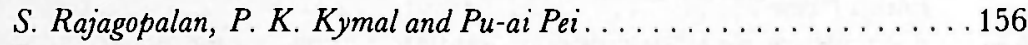

$5.6 \quad$ References . . . . . . . . . . . . . . . . . . . . . . . . . . . 161

6. FAMILY HEALTH AND SEASONAL WELFARE . . . . . . . 163

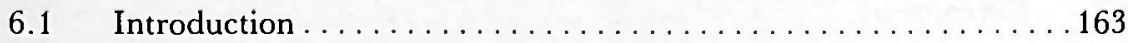

6.2 Seasonality and the Growth of Infants in a Gambian

Village, M.G.M. Rowland, Alison Paul, A. M. Prentice,

Elisabeth Muller, Melanie Hutton, R.A.E. Barrell, and

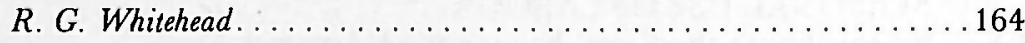

6.3 Poverty, Housing and Disease, B. B. Waddy . . . . . . . . . . . 175

6.4 Seasonal Health Problems in the Zaria Region,

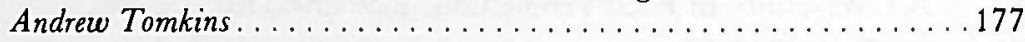

6.5 A Study of Childhood Disease in Tanzania, James P. Goetz . . . . . . 182

6.6 Pastoralists and Cultivators in Bagamoyo District,

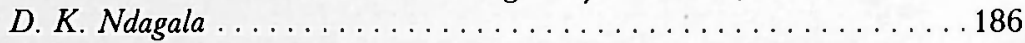

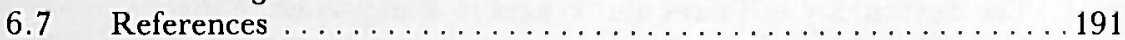

viii 


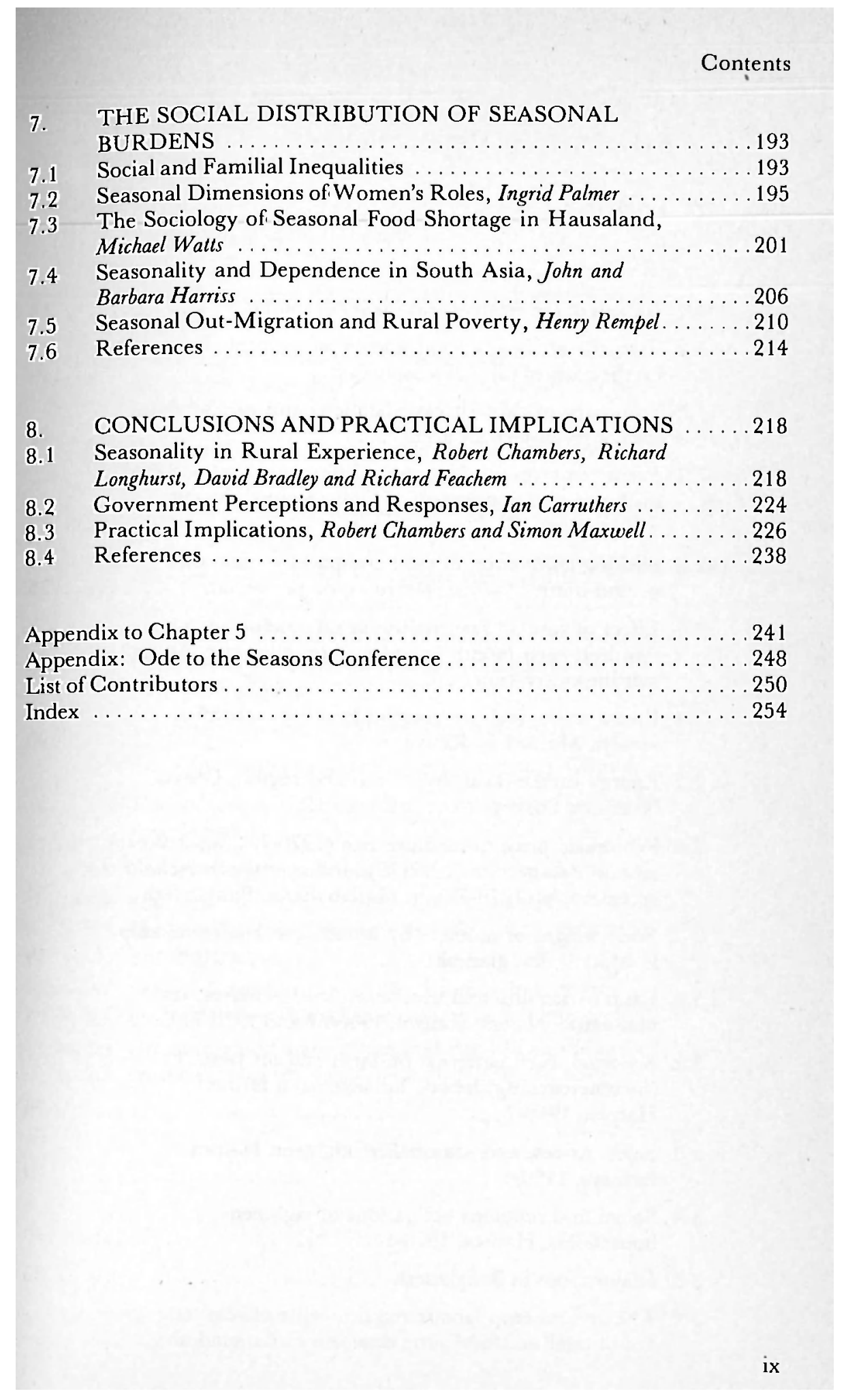




\section{LIST OF TABLES}

1.1 Indices of the relative seasonality of rainfall $\ldots \ldots \ldots \ldots 13$

1.2 Provisional classification scheme of tropical climates on the basis of rainfall seasonality

1.3 Summary of climatic classifications and rainfall data for the six case-study areas . . . . . . . . . . . . . . . 22

2.1 Predicted crop production in different climates, based on 3 per cent conversion of light received during wet months

2.2 Shifting cultivation of rice: comparative data on person-hours of labour per rice crop per hectare

2.3 Effect of rainfall seasonality on the amount of work required each month in order to produce rice through shifting cultivation $\ldots \ldots \ldots \ldots \ldots \ldots \ldots \ldots \ldots \ldots$

2.4 Breast milk yield per stage of lactation according to season, Machakos, Kenya . . . . . . . . . . . . . . . 43

2.5 Energy intake (kcal) by season and region, Ghana Nutrition Survey

2.6 Wholesale price of medium rice (1976-77), agricultural labourer wage rate (1977-78), and average household cereal stocks (1976-77), in Matlab thana, Bangladesh

2.7 Body weight of mothers by month and landownership in Matlab, Bangladesh . . . . . . . . . . . . . . . . . . 59

3.1 Land ownership and use, seven cattle-owners, ten non-cattle-owners, Hanwa, 1966/67 and 1970/71

3.2 Seasonal work patterns: on-farm and off-farm (income-earning) labour for seventeen farmers, Hanwa, 1966-7...................... 76

3.3 Sales, prices, and seasonality: eighteen Hanwa farmers, 1970-1

3.4 Social and religious obligations of eighteen households, Hanwa, 1970-1 . . . . . . . . . . . . . . . . 79

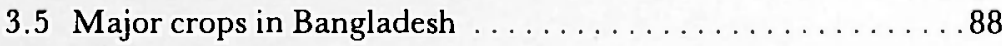

3.6 The annual crop labour requirements of selected 'traditional' and 'new' crop rotations in Bangladesh 
4.1 Deaths from diarrhoeal disease at various ages in England and Wales, 1911 and 1971, and in Mexico

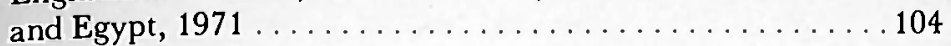

4.2 Seasonal transmission of guinea-worm infection in various geographical regions

5.1 Correlations between the average monthly distribution of births and the mean minimum temperature nine months previously, 1962-4

5.2 Percentage distribution of leading causes of death for infants under one month old and adults over forty-five years in Matlab DSS, 1972-73

6.1 Simplified annual events calendar for the Gambian village of Keneba

6.2 Diseases of particular prevalence in the Zaria region of northern Nigeria

6.3 Diseases of particular prevalence among different population groups within one village area in Zaria region of northern Nigeria. . . . . . . . . . . . . 180

6.4 Diseases of particular prevalence in Bagamoyo District, Tanzania . . . . . . . . . . . . . . . 183

7.1 Seasonality in selected South Asian regions . . . . . . . . . 207

8.1 The variation of various factors by month in Gambia . . . . . 221

8.2 The variation of various factors by month, in Matlab, Bangladesh ......................... 222

8.3 Checklist on the policy implications of seasonality . . . . . 237 Appendix Seasonal measures of births (and marriages) by month Table 5.1 of birth, for countries with available data, grouped

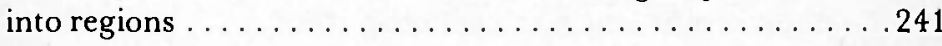

Appendix Seasonal measures of deaths, by month of death,

Table 5.2 for countries with available data, grouped into regions

Appendix Comparison of state urban and rural birth indices of Table 5.3 seasonality for ten states, by month, India 1962-64 


\section{LIST OF FIGURES}

1 Schematic 'map' of some of the factors discussed in this book . . . . 7

1.1 Spatial distribution of rainfall regime types in the tropics . . . . . 12

1.2 Seasonality index maps for Brazil, the Indian Subcontinent and Sub-Saharan Africa ............ . 14

1.3 Sub-Saharan Africa: dry months per annum $\ldots \ldots \ldots \ldots \ldots$

1.4 Sub-Saharan Africa: tropical climatic types based on rainfall seasonality . . . . . . . . . . . . . . . . . 19

1.5 The Indian Subcontinent and Brazil: tropical climatic types based on rainfall seasonality

1.6 Bangladesh, showing District boundaries and the location of Matlab in Comilla District, which is in the Matlab

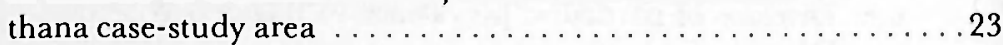

1.7 South India, showing boundary of Tamil Nadu and the location of North Arcot and Thanjavur Districts

1.8 Map of the main area of bimodal climate in East Africa, locating the Machakos and Bagamoyo Districts, both of which have $\mathrm{E} 3^{*}$-type climates .................. 26

1.9 The three case-study areas in West Africa in relation to the main climatic zones

2.1 Predicted maximum yield of agricultural crops in tropical climates differing in rainfall seasonality .

2.2 Seasonal pattern of food availability for Matungulu and Mbiuni locations of Machakos District

2.3 Graph of food storage at farm level over time, Machakos

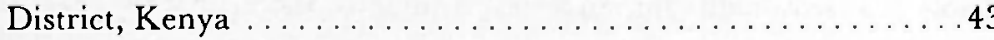

2.4 Mean body weight of 216 mother children pairs by month of observation, Matlab thana, Bangladesh

2.5 Median of suckling time during 8 hours of daytime observation and month of observation of 216 mother child pairs, Matlab thana, Bangladesh

2.6 Number of patients admitted to ICDDR,B hospital during calendar 1976 and 1977 by etiology and month of admission

xii 
2.7 Household food stocks on the day of interview by month of interview of eight landowner households and seventeen landless households, Matlab thana, Bangladesh

3.1 Median dates of planting and harvesting in Hanwa village, northern Nigeria, $1966 / 7 \ldots \ldots \ldots \ldots \ldots \ldots \ldots \ldots$

3.2 Food consumption in relation to work done for cattleowners and non-cattle-owners in Hanwa village, northern Nigeria, 1970/7

3.3 Labour requirements and milk production in a flock of

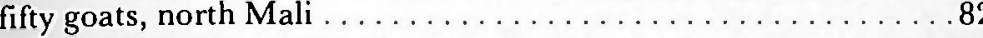

3.4 Labour requirements and milk production in a herd of twenty-five camels, north Mali

3.5 Labour requirements and milk production in a herd of twenty-five cattle, north Mali . . . . . . . . . . . . 84

3.6 The wholesale price of coarse rice in Bangladesh: an adjusted seasonal index for 1953-68 and 1968-76

3.7 An index of real daily wage rates for agricultural labour

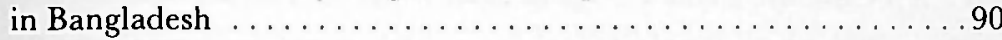

3.8 The impact on labour requirements of changes in cropping

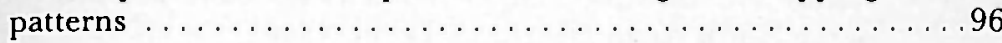

3.9 The impact on labour requirements of changes in cropping

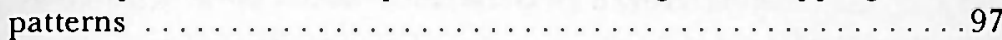

3.10 Histograms showing the seasonal distribution of crop labour requirements in four administrative districts of Bangladesh .

4.1 Hourly readings of faecal coliform and streptococci concentrations with associated rainfall and river temperature data

4.2 Rainfall and the incidence of respiratory illness in Trinidad; data recorded in 1961-62 . . . . . . . . . . . . . . . . 113

4.3 Malaria prevalence and density among mothers and infants 0-6 months old in Gambia, 1976

4.4 Malarial antibody levels in the blood of mothers and infants in Gambia, 1976, and in cord blood samples

4.5 Seasonal variations in rainfall and in the man-biting rate of two species of mosquito, Anopheles funestus and Anopheles gambiae sensu latu, at Tingrela, Upper Volta.

4.6 Rainfall, kala-azar diagnoses, abundance of sandfly vector, and presumed infection potential, Kitui District of Kenya, 1961-2 


\section{List of Figures}

5.1 A simplified diagram of some of the main interrelationships likely to bring about a seasonal fluctuation in births . . . . . . 136

5.2 A simplified diagram of some of the main interrelationships likely to bring about a seasonal fluctuation in deaths . . . . . . 140

5.3 Average monthly percentage variation in births and deaths by region

5.4 The monthly percentage distribution of 'conceptions' and the mean minimum air temperature for the urban population of the Punjab, over a three-year period (1962-64) . . 147

5.5 Deaths and rainfall in two Indian states . . . . . . . . . . . 148

5.6(i) Live births in the Matlab Surveillance System (both areas) 1972-1974 by month and fitted regression curve . . . . . . . . 151

5.6(ii) Total deaths in the Matlab Surveillance System (both areas) 1972-1974 by month and fitted regression curve . . . . . . . . 151

5.6(iii) Neonatal mortality rates in the Matlab Surveillance System (both areas) $1972-1974$ by month and fitted regression curve.

5.7 Climatic seasonality and agriculture in Tamil Nadu

5.8 The seasonality of births and conceptions in rural Tamil Nadu, and the seasonality of women's agricultural work in the North Arcot District of Tamil Nadu . . . . . . . . . . . . 158

6.1 Contrasting growth in Gambian children born in different seasons . . . . . . . . . . . . . . . . . . 168

6.2 Seasonal variations in breast milk intake for babies at Keneba, Gambia. . . . . . . . . . . . . . . . . . . 169

6.3 Seasonal variations in energy intake of women in Keneba,

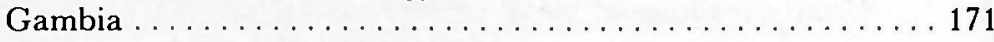

6.4 Gambia: weight loss and gain among women in Keneba, showing that even pregnant women lose weight during

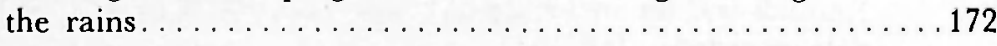

6.5 Gambia: seasonal changes in disease prevalence, Keneba village.............................. 173

6.6 The time of year at which babies are completely weaned off the breast in the Malumfashi area, northern Nigeria.

6.7 Monthly occurrence of cases of lower respiratory tract disease and of measles in children under 15 years admitted to Bagamoyo District Hospital, Tanzania, $1976 \ldots \ldots \ldots \ldots \ldots 184$

6.8 Monthly occurrence of cases of severe protein-energy malnutrition (PEM), diarrhoea, and malaria/fever in children under 15 admitted to Bagamoyo District Hospital, Tanzania, 1976 
The process which has led to this book was sparked off by the discovery in a seminar at the Institute of Development Studies at the University of Sussex that in both northern Nigeria and a part of Bangladesh there was a peak in births in the late wet season. This led organisers and participants to examine the ramifications of tropical seasonality, paying particular attention to interrelationships among various disciplines-geography, economics, sociology, medicine, nutrition and demography, to mention but some. The Conference on Seasonal Dimensions to Rural Poverty which followed was organised jointly by Robert Chambers and Richard Longhurst of IDS and by David Bradley and Richard Feachem of the Ross Institute of Tropical Hygiene, London School of Hygiene and Tropical Medicine. The conference was financed by IDS, and held from 4-7 July 1978 .

This book is based on the conference papers and discussions, but it is not a conventional conference volume. Arnold Pacey worked out a logical framework, reflected in his schematic diagram (page 7). With the generous consent of contributors, he did the major work of shortening, editing, and organising the papers into coherent chapters, with the other two editors undertaking the later stages. The final chapter includes practical implications contributed by the editors and by many others who have corresponded from different parts of the world. Elsewhere in the book, sections for which no author is cited are the joint responsibility of the editors.

In summary, the findings of the conference and its follow-up suggest that most of the very poor people in the world live in tropical areas with marked wet and dry seasons. Especially for the poorer people, women and children, the wet season before the harvest is usually the most critical time of year. At that time adverse factors often overlap and interact: food is short and food prices high; physical energy is needed for agricultural work; sickness is prevalent, especially malaria, diarrhoea and skin infections; child care, family hygiene, and cooking are neglected by women overburdened with work; and late pregnancy is common, with births peaking near harvest. This is a time of year marked by loss of body weight, low birth weights, high neonatal mortality, malnutrition, and indebtedness. It is the hungry season and the sick season. It is the time of year when poor people are at their poorest and most vulnerable to becoming poorer.

Some of these points, and others in this book, are almost embarrassingly obvious; and some are surprising. Rural people have always known about the seasons, but planners and policy-makers have difficulty grasping their full significance. Urban-based professionals travel less during the rains and so underperceive adverse seasonality. In addition, specialisation makes it difficult for professionals to see the seasonal linkages between food, energy, morbidity, malnutrition, indebtedness, dependence, exploitation, and poverty. 
Preface

It is difficult to find any aspect of rural life in the tropical third world which is not touched by seasonality. In consequence, any attempt to come to terms with it involves many disciplines. Lip-service to multidisciplinarity is easy, but to bring many professions together invites the mutual incomprehension of a Tower of Babcl. One good thing about tropical seasonality is the common framework it provides for different disciplines and professions, making communication simpler and new insights more likely. We hope that readers will not limit themselves to what they find more familiar but will launch out into domains other than their own and share the excitement of finding crossdisciplinary linkages, many of which have taken us by surprise, and many of which no doubt remain to be uncovered.

We hope, too, that this is only a beginning. Many research questions and practical implications are suggested by seasonal analysis. Perhaps all rural research and all rural planning should have a seasonal dimension; perhaps counter-seasonality - offsetting biases against seeing the hungry and sick seasons, and then offsetting adverse seasonality itself - should be in the minds of all who are concerned with rural poverty and rural development.

Many people have contributed to the development of this book. The earlier work of Susan Schofield on seasonal nutrition has been a recurrent point of reference and source of ideas. Those who presented the case studies-from Gambia, Mali, northern Nigeria, Kenya, Tanzania, Tamil Nadu and Bangladesh - are named in the text. Others have contributed special studies. The research on the seasonality of births and deaths was carried out by the Centre of Population Studies at the London School of Hygiene and Tropical Medicine. The families and friends of contributors and editors have suffered in silence or otherwise. Many at IDS have helped, not least with tolerance. Philippa Baxter, Teresa Dearlove, Lyn Gorman and Ann Segrave have given administrative and technical advice and support. Anita Hall organised the original conference and made it a pleasure. Pauline Cherry drew the diagrams, and Christopher Heaps most of the maps. Above all, we want to thank Susan Saunders. She played a major part in preparing the conference, managed the follow-up to it, and typed, checked and organised the final manuscript, and all this with a calm, good humour and accuracy which we can only envy and admire.

Robert Chambers

Richard Longhurst

Figure 1.1 has been redrawn from a map in K. Nieuwolt Tropical Climatology and is reproduced by permission of the publishers, John Wiley. 


\section{INTRODUCTION}

\section{Robert Chambers}

I settled down in the village on August 28 last year but by mid September I had already learned of the hard days of the 'enzala', i.e. hunger or famine which annually occurs between February and May. The food grains harvested in December have run out and the next harvest begins in May. It is certainly a tragedy that officialdom (e.g. agricultural reports, etc.) say nothing about this annual plight. But this is a fact which everyone in the village knows .... I cannot forget how on two different occasions on exchanging greetings as I arrived to carry out interviews the women informed me that they had not eaten anything for three days.

(Joseph Ssennyonga, describing research in western Kenya: Ssennyonga, 1976, p. 11n)

\section{Explaining rural poverty}

The extent of rural poverty needs no elaboration. What has perhaps been new over the past few years has been the increasing concern with the poorer rural people. It is notorious that the poorer majority of rural people in third world countries have not shared proportionately in the fruits of economic growth - that they have usually benefited rather little, or not at all, or become worse off. The explanations are many. Rural poverty is variously and to varying degrees attributed to a continuing condition of undevelopment; to an active process of underdevelopment and the extraction and transfer of surplus through colonialism, neo-colonialism and the forces of capitalism and unequal exchange; to ill-health and poor nutrition; to war; to natural disasters; to famines; to population growth and its pressure on resources; to degradation of the environment; to the impact of inappropriate capital-intensive technology; and to the failure of government services to provide for basic needs. Other factors mentioned are the 'talents effect' (Pearse, 1977) - the tendency for those who are relatively better off and more powerful in rural areas to capture the benefits of programmes and to accumulate wealth; and the exploitation of rural areas and people by urban areas and people (Lipton, 1977). There are many persuasive explanations, and many variants of them. One may reasonably conclude that there are many forces which act and interact to sustain, deepen and extend rural poverty.

Compared with these explanations, rather little attention has been paid to tropical wet-dry seasonality. Climate has been out of fashion as an explanation of poverty; but the location of richer countries in temperate latitudes and poorer countries in the tropics is so marked that climatic factors cannot lightly be dismissed, whether they are fashionable or not. One possibility is that climatic influences have been underestimated because of a failure to see that 
Seasonal Dimensions to Rural Poverty

seasonally adverse factors interact and reinforce each other at certain times of the year. Tropical seasonality tends to be overlooked anyway; and where it is noticed, it is usually along a single disciplinary dimension. It is only rarely (as for example in Haswell, 1975, Schofield, 1974) that the interactions of multiple seasonal adversities (medical, nutritional, agricultural, family, economic, social, and so on) have been analysed.

Against this background, we can ask:

(1) are there reasons why tropical seasonality should tend to be overlooked?

(2) what linkages are there between concurrent seasonal stresses and adversities?

(3) what seasonal factors matter-when, where, how much, and to whom?

(4) does seasonality make some people poor and keep them poor?

(5) what practical measures does seasonal analysis suggest?

This book seeks to open up discussion of topics such as these, to present some of the relevant research that has been done in Africa and South Asia, and to assess the implications.

Two caveats are in order. First, a seasonal perspective does not necessarily imply an explanation of rural poverty with some sort of causal primacy. This is simply one mode of analysis among many, but one which has been neglected. Second, there is no intention to draw attention away from other explanations. Self-critical introspection is often uncomfortable but salutary. To the extent that observers have vested interests in rural poverty, they may prefer explanations or modes of analysis which do not threaten those interests. Some from rich countries may prefer to find explanations in, say, population pressure on resources rather than in low commodity prices; and some from urban sectors in third world countries may prefer to find explanations in unequal exchange between countries rather than unequal exchange between the urban and rural sectors within countries. In adopting a seasonal mode of analysis we must be careful that we are not subconsciously attracted by an activity which conveniently diverts attention from more painful issues such as these. At the same time we may note that there is nothing in a seasonal mode of analysis which excludes other explanations listed; to the contrary, it should illuminate the manner in which they operate.

The case for exploring a seasonal mode of analysis rests on two further arguments: first, that there are systematic biases against this mode, tending to its neglect; and second, that the hypothesis that adverse seasonalities operate to keep poor people poor or make them poorer is sufficiently plausible to deserve examination. These will be considered in turn.

\section{Seasonality unobserved}

Rural poverty itself, seasonal or not, tends to be underperceived (Chambers, 1980). Reasons for this are that officials, researchers and other travellers in rural areas tend to meet the wealthier and more influential people; they tend to meet men rather than women; and they often visit or study model villages or projects which have received special attention. This underperception of poverty is reinforced by four distinct biases which make it more difficult to find out what happens to the poor under the adverse conditions of rainy seasons: 
Introduction

(1)

larmac bias. The areas visited during the rains tend to be those accessible by all-weather roads, especially tarmac. These tend to be the more prosperous and more densely settled areas closer to urban centres, and less exclusively agricultural and less subject to seasonality than those which are more remote and harder to reach. Often, too, the better-off people have bought up plots beside tarmac roads to become a roadside elite (Ssennyonga, 1976, pp. 9-10) and built good houses on them, while the poorer people who are more vulnerable to seasonal problems have shifted back out of sight.

(2) activity bias. During the rains there is often much activity in the fields. This can attract attention away from what goes on in the villages, in the houses and huts, where those who are weaker, sicker and shorter of food, including women and children, may be found.

(3) imigation bias. John Harriss (1977, pp. 30ff) has shown for India for the late 1960 s and early 1970 s, that social science research was concentrated in the richer areas with assured irrigation, to the neglect of vast areas relying only on rainfall. Indeed, irrigation generally exercises an attraction which draws to it disproportionate attention and research. Irrigated agriculture has, of course, its own seasons. But compared with rainfed agriculture, in the seasonal wet-dry tropics, it is more reliable, provides a steadier supply of crops to cultivators and work to labourers, and may spread the peaks of adverse factors more around the year, weakening their interaction.

(4) dry season bias. Perhaps the most significant bias results from the tendency for rural visits and research to be undertaken in the dry seasons. (See Appendix for a little verse which touches on this subject.) There may be exceptions with epidemiologists and agriculturalists who have to work during the rains. But generally, officials, experts, researchers and professionals of all sorts are restricted in their travel at those times. Some areas are officially closed to movement and others are inaccessible unless on foot or by horse, hovercraft, helicopter or aircraft. In parts of the South Sudan, for example, there are months every year when the roads have become impassable but the rivers are not yet high enough for travel by boat. During rains, the risks of getting stuck or damaging a vehicle are high. And rains and mud are physically unpleasant. So research institutes concentrate their fieldwork in the dry season. In a revealing sentence, a manual on assessing rural needs warns about the unexpected in rural surveys and says 'once, the jeeps needed for transporting the interviewers were recalled for a month during the few precious months of the dry season' (Ashe, 1979, p. 26, our italics). The resulting dry season bias gives exaggerated impressions of wellbeing, as with nutrition surveys conducted after harvest when food is abundant. The privations of the wet hungry season, the period, in Ssennyonga's words, of 'slow and quiet famine' (1976, p. 8), go unseen. 


\section{Seasonal Dimensions to Rural Poverty}

In addition to these specific biases, there is a more general anti-seasonal bias in data collection and processing. Much seasonal analysis requires detailed year-round data; but these are costly to obtain. They require sustained and expensive organisation, especially difficult for academic researchers with teaching obligations. But even when year-round data are obtained, they may not be processed because both researchers and funds tend to be exhausted once fieldwork is over, and because seasonal data are bulky and burdensome if they have been well collected. Short surveys are less risky and more digestible and lead to earlier and easier consummation. Thus 'one-point' nutrition surveys are more common than seasonal all-the-year-round surveys (Schofield, 1974, p. 22). With economic data, too, a seasonal breakdown may be all too rare, and C. T. Kurien's lament for Tamil Nadu may apply elsewhere:

To estimate the percentage of agricultural labourers living below the poverty line we need information about man-days worked in a year and wage rates. It is impossible to get accurate data relating to these which will reflect the wide variety of patterns . . . during different periods of the

year. (1976, p. 35)

It is not surprising that a subject should be neglected for which data are scarce because they are difficult and laborious to collect and analyse.

Finally, disciplinary specialisation hinders the understanding of seasonal linkages between different factors. There is no discipline, except perhaps geography, which could claim competence to explore the links between climatic seasons and poverty. But the geographical school which sought explanations of development and undevelopment in terms of climate long since ceased to be respectable; and as climate itself has been subjected to sophisticated mathematical analysis, geographers and climatologists may have been forced to narrow their vision more and more to the physical aspects of climate and their measurement and analysis. As for other disciplines, if they focus on seasonality, the sustained organisation for data collection and processing may make such heavy demands that they have no time or energy for considering concerns other than their own. They may then identify some seasonal changes which deepen poverty but not explore how these are linked with others. An economist may note seasonal fluctuations in wage levels, but not in the incidence of malaria. A doctor may observe seasonal patterns of morbidity but not of indebtedness. In any case, even without the special difficulties of seasonal studies, professional brainwashing trains observers in tunnel vision. They see those parts of the whole on which they have learnt to direct a light but they see them at the cost of a balanced view. Rural people, unimpeded by professional blinkers, often see more of the whole. For outside professionals to see that whole may require many disciplinary searchlights; and these are expensive and difficult to bring together, especially between the social sciences and the natural sciences.

To the extent that these biases operate, it is not surprising that seasonal dimensions to rural poverty should be neglected.

\section{An initial scenario}

The suggestion that tropical seasonality may reinforce rural poverty can most concisely be presented as a composite scenario, in which each statement is a hypothesis open to testing. 
The scenario starts with a tropical environment where a wet season follows a dry season. and where cultivation is practised. Towards the end of the dry stason. food becomes scarcer, less varied and more expensive. The poor peole. who may be landless or have small plots of land, experience food shortage more acutely than their less poor neighbours. Some migrate in search of work and food. Others undertake non-agricultural activities near their homes in which the returns to labour are low. More work is involved in fetching water.

When the rains come, land must be prepared, and crops sown, transplanted and weeded. If animals are used for ploughing, they are weak after the dry season. Delays in cultivation reduce yields. For those with land, food supplies depend on the ability to work or to hire labour at this time. For those without land. work in the rains and at harvest often provides the highest wages of the year. This is the time of year when food is most needed for work, but it is also the hungry season when food is shortest and most expensive. It is, too, a sick season when exposure to tropical diseases is at its greatest, when immunity is low. and when vomen are most likely to be in late pregnancy. So the rains bring crisis. Vulnerable to hunger, sickness and incapacity, poor people are undernourished and lose weight. Seasonal stress drives them into debt and dependence. The knowledge that there will be future seasonal crises constrains them to keep on good terms with their patrons. They are thus screwed down seasonally into subordinate and dependent relationships in which they are open to exploitation. The poor are subordinated to the less poor and the weak to the strong. Stress is passed down to the weakest - women, children, old people and the indigent. Sometimes the screw becomes a ratchet, an irreversible downward movement into deeper poverty as assets are mortgaged or sold without hope of recovery. This is, then, a time when poor people are kept poor and a time when they become poorer.

With the harvest things improve. Grain prices are lower, a benefit to those who must buy food but a disadvantage to those small farmers who must sell their crops to repay debts or raise money for ceremonies. After the harvest, ceremonies, celebrations and marriages take place. Body weights recover. The dry season sets in. And then the cycle begins all over again.

There are dangers in presenting this composite scenario. First, it is written descriptively but each statement is in fact a separate hypothesis which may be mistaken for a widely established truth. An ideal type may be created in the mind of the reader, with which experience will not fit. Many exceptions may be found, and each environment must be analysed separately.

A second danger lies in extrapolation from situations of exceptional seasonality to rural areas more generally. Seasonality may be most studied and written about where it is most marked. This book, for example, deals with savannah areas in Africa and monsoon climates in Asia rather than with equatorial areas where seasonal contrasts are less. Within those regions, the book takes some half-dozen areas for closer examination. These case-study areas have been chosen, not only for their seasonal characteristics but also because of the availability of data. This may seem to have biased the choice unduly, but when the distribution of rural population in the third world generally is examined, this appears less distorting than at first sight. While exact figures cannot be given, well over half the rural population of the third 
Seasonal Dimensions to Rural Poverty

world outside China probably lives in areas characterised by high climatic seasonality (ranging from D3 to F5 in the classification presented in Chapter 1). Such areas include most of the Indian Subcontinent and much of Africa south of the Sahara, besides parts of Central and South America and of Southeast Asia. After excluding areas of lower seasonality, the affected rural population in the Indian Subcontinent alone was over 600 millions in 1980 and in Sub-Saharan Africa over 200 millions.'

A third danger in making generalisations about seasonality is that agricultural seasonality does not always reflect the seasonality of climate because of irrigation. By using stored or non-seasonal water (whether from dams, rivers, or the ground) cultivation may be artificially spread more around the calendar, bringing new and different flows of food and income, labour demands and threats to health. As irrigation spreads, especially in the Indian Subcontinent, annual patterns of variation along many dimensions can be expected to change.

\section{An approach for all disciplines}

Seasonal variations occur in most of the human activities and natural processes which directly concern rural life. The schematic 'map' of some of the factors discussed in this book (see Figure 1) illustrates the considerable range of elements concerned in this, and some of their linkages. It is evident that many disciplines are required for a comprehensive understanding of seasonality as it affects rural people. With this in mind, the chapters which follow are organised to concentrate in turn on climate (Chapter 1), nutrition (Chapter 2), agricultural economics (Chapter 3), epidemiology (Chapter 4), and demography (Chapter 5). These specialised chapters reveal shared insights which later chapters draw together. Thus Chapters 6 and 7 are concerned with the welfare of poor rural people and its seasonal variations, Chapter 6 dealing with family health and Chapter 7 with social issues. Finally, in Chapter 8, an attempt is made to derive the more important practical implications for rural development policy and practice.

The experience of the conference which gave rise to this book and of subsequent work and correspondence has shown that seasonal analysis has a capacity both to excite intellectually, and to draw together the different professions. It provides a frame of questions which specialists can share, and which makes it easier to accept and relate to the concerns and findings of other disciplines. The divisive effects of professional training and of departmentalism are well known, and often give rise to complaints of lack of coordination and lack of integration in rural development. Seasonality provides one integrating concept which, as this book seeks to show, makes it easier to understand processes in rural environments and in rural life, and easier to see interactions between sectors and between programmes.

The hope is, then, that this book will do three things: first, raise awareness of seasonality and of seasonal linkages; second, provide practitioners and researchers of different departments and disciplines with a common frame of questions, which will draw them together; and third, and above all, help to identify feasible measures which will make things less hard for those rural people who, so often unseen, suffer seasonal hardship and impoverishment. 


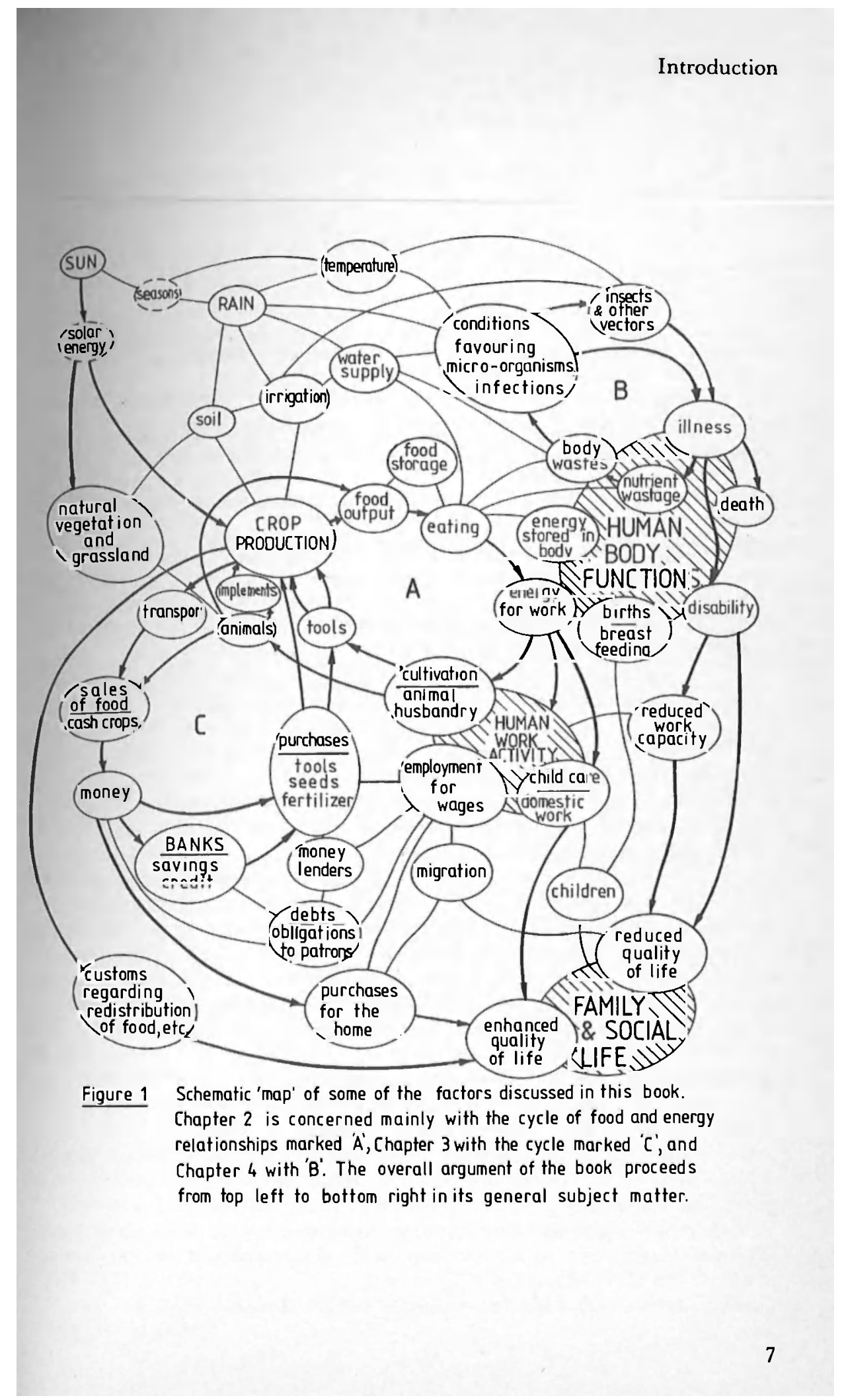


Seasonal Dimensions to Rural Poverty

\section{Note}

1. These very approximate estimates have been derived from three sources: (1) the map presented by Walsh in Chapter 1 below; (2) estimates of world rural population by country ij 1975, supplied by FAO, and updated; (3) maps in Davies (1973)

\section{References}

Ashe, Jeffrey (1979), Assessing Rural Needs: a Manual for Practitioners, VITA (Volunteers in Technical Assistance), 3706 Rhode Island Avenue, Mt. Rainier, Maryland 20822, USA. Chambers, Robert (1980), 'Rural Poverty Unperceived: Problems and Remedies' World Bank Working Paper No. 400, Washington D.C.

Davies, H.R.J. (1973), Tropical Africa: an Atlas for Rural Development, Cardiff, University of Wales Press.

Harriss, John (1977), 'Bias in Perception of Agrarian Change in India', in Green Revolution?' Technology and Change in Rice-Growing Areas of Tamil Nadu and Sri Lanka, ed. B. H. Farmer, London and Basingstoke, Macmillan.

Haswell, Margaret (1975), The Nature of Poverty: a Case-history of the First Quartercentury after World War II, London and Basingstoke, Macmillan.

Kurien, C. T. (1976), Rural Poverty in Tamil Nadu, India, Rural Employment Research Programme, Working Paper, Geneva, International Labour Office.

Lipton, Michael (1977), Why Poor People Siay Poor: Urban Bias in World Development, London, Temple Smith

Pearse, Andrew (1977), 'Technology and Peasant Production: Reflections on a Global Study', Development and Change, 8 (2).

Schofield, Sue (1974), 'Seasonal Factors Affecting Nutrition in Different Age Groups and Especially Pre-school Children', Journal of Development Studies, 11 (1), pp. 22-40.

Ssennyonga, Joseph (1976), 'The Cultural Dimensions of Demographic Trends', Populi 3 (2). 


\title{
Chapter 8 \\ CONCLUSIONS AND PRACTICAL IMPLICATIONS
}

\author{
8.1 Seasonality In Rural Experience* \\ Robert Chambers, Richard Longhurst, David Bradley and \\ Richard Feachem
}

\section{The seasonal dimension}

The objectives of rural development are many. The definition given by the World Bank is

a strategy designed to improve the economic and social life of a specific group of people - the rural poor. It involves extending the benefits of development to the poorest among those who seek a livelihood in the rural areas. The group includes small-scale farmers, tenants and the landless. (World Bank, 1975, p. 3)

Accepting this definition, analysis of the seasonal experience of rural poverty adds an extra dimension and helps clarify objectives. Thus one major objective can be seen as enabling poorer rural families to secure adequate stocks and flows of food and cash around the whole of the year. Then by concentrating on times of the year when food stocks and cash flows are inadequate, and when poor families fall below an acceptable threshold, we may be able to direct attention to more cost-effective interventions. More may be achieved in action against poverty by enabling poor families to rise above these thresholds at bad times of the year than by trying to generate entirely new year-round livelihoods.

In order to see how this approach might be applied, we will first review conclusions from earlier chapters about the way seasons affect experience of poverty. In regions without marked seasons, the poor may have a hard grind all the year round, with no sharp crises, but no let-up either. But where there are sharp seasonal contrasts, there are times each year when life is relatively easy (usually in the early dry season) and times when the experience of poverty reaches crisis point (usually during the rains and up to the harvest).

For pastoralists, the seasonal crisis tends to come earlier than for cultivators. During the late dry season, the work involved in drawing water for animals is at a peak, but milk supplies are very low. Soon after the rains come there is less work and more milk (Swift, Section 3.3; Ndagala, Section 6.6).

For cultivators, the most critical period begins with the rains. Future food supplies and cash income depend upon timely planting of crops. Poorer farmers are often delayed by lack of inputs - whether seeds, fertilizers, irrigation water, or draught power. Draught animals, for those farmers who use them, are weak after the dry season. Some farmers have to delay preparing

-Much of this material originally appeared in Discussion Paper 142, Institute of Development Studies, University of Sussex. 
their own fields and planting while they earn some money labouring for better-off farmers. For most rural people, heavy and urgent energy demands have to be met. Labourers benefit from being able to get work, but many people are in energy deficit and lose weight (Chapter 2).

The rainy season is also often the least healthy time of year. Diseases differ in their seasonalities, but some of the more serious and debilitating peak during or just after the rains (Chapter 4). These often include malaria, diarrhoeal diseases (the latter especially where the wet season is also a hot season), guinea-worm disease, dengue fever, infections of the skin, and even snake-bite (Warrell and Arnett, 1976). This is also a time when the development of protein-energy malnutrition and perhaps other stresses contribute to low immune response.

The rainy season is a bad time for mothers and children. Anticipating hard work, mothers wean their infants or, if they continue to breast-feed, may only be able to do so less regularly (Chapters 2 and 6 ) and less milk may be consumed at each feed (Whitehead et al., 1978). Food preparation becomes more hurried and the diet less adequate, varied and nutritious (Schofield, 1974). There is more bacterial growth in food left standing in humid conditions (Barrell and Rowland, 1979). Late pregnancy is common and births peak, but body weights of mothers and birth weights of babies are both low, and the rate of neonatal mortality rises (Chapter 5). Child care is neglected by mothers who have to work. Pregnant and lactating women are weakened by disease and work, and those in the poorer, smaller families are especially vulnerable because of the need to work when work is available; one instance is of a Gambian village where women in the last trimester of pregnancy were observed to lose an average of $1-4 \mathrm{~kg}$ of weight during the worst month, August (Whitehead et al., 1978; see also Figure 6.4 here).

In highly seasonal conditions of the sort described, being poor means being vulnerable, at the end of every dry season, to any lateness or inadequacy of the rain; and then, in every wet pre-harvest period, being short of food and being forced to obtain it on adverse terms. Food prices are high. Those who are less poor have better food stocks and can anyway afford the higher prices. But the poorer people are often driven to borrowing under duress or to distress sales. They sell or mortgage assets, or their future crops or labour. They eat less than they need at this time of hard work, and they lose weight. Any sickness has a crippling effect on a family's independence. Poor people are hypervulnerable to contingencies. Before harvest is a time when dependent and exploitative relationships are likely to begin and to be reinforced and deepened.

With harvest, food is abundant. Debts are repaid, but often at high rates of interest, especially when the money must be raised by selling food crops when the prices are low. But food intake recovers in both quantity and quality. Body weights rise, there is less illness and mortality rates decline. There are celebrations and marriages. There is a peak in rates of conception. And then gradually as the dry season progresses, food becomes scarcer, cash reserves diminish, and the cycle begins all over again.

\section{Case-studies}

In this book, the examples of the case-study areas may help to give clear in- 
Seasonal Dimensions to Rural Poverty

dividual pictures of what seasonality may mean and also to show how the generalised description of seasonal factors given above has to be modified for individual locations. A crude but telling way of summarising findings is by means of Tables 8.1 and 8.2 which compare the case-study areas in Bangladesh and Gambia. ('Bangladesh', 'Gambia' and 'northern Nigeria' as used below refer only to the case-study areas.) Climatic seasonality is greater in Gambia, where there is only one cultivation season, from June to October. In Bangladesh this is slightly less marked with a longer, wetter rainy season: agricultural seasonality is further reduced by irrigation and high water tables. The information that can be summarised in these two tables is obviously limited: both tables support the findings of the general scenario but different socio-economic conditions lead to qualifications about the distribution of seasonal stress. In Gambia, the main farming load is taken by the women who grow swamp rice while the men cultivate the less labour-intensive millets. However, in Bangladesh, women have less responsibility for field work; in many families, their main agricultural work is the post-harvest processing of rice. Another contrast is that the rural population of Gambia is still dependent on subsistence crops grown on their own land, while in Bangladesh, many of the rural poor are landless labourers, dependent on wages and the purchase of food. Thus Table 8.2 includes columns representing wages and food (rice) prices, factors which have a very strong influence on the plight of the poor in Bangladesh.

It cannot be emphasised too strongly that, notwithstanding the findings reported in this book, each environment should be examined independently. This will reveal many different patterns and will in time lead to a more subtle and varied classification of seasonal types, as can be illustrated by three points.

First, a major qualification to the scenario and generalisations applies in much of northern India where there are three main seasons - hot wet, cold dry, and hot dry - and where, with irrigation, stresses of heat, work and sickness occur together in the hot dry season.

Second, even where rainfall is bimodal, or where there is more complex cropping under irrigation, seasonal peaks and stresses still occur. In the East African cases, for example, although bimodal rainfall has smoothing effects, there remain marked peaks in labour demand for agriculture.

Third, despite climatic similarity between Gambia and northern Nigeria, there are many differences, attributable to four factors. The first is in the division of labour; in rural northern Nigeria the wives of the settled cultivators (of child bearing age) are secluded. Men carry out the bulk of the farm work and this implies that the energy expenditure of women here is less than that of Gambian women. The second difference appears in the energy returns of crops: compared with sorghum in northern Nigeria, rice in Gambia probably has a far lower ratio of calories gained in the crop yield to calories expended as human energy input. Sorghum is grown in Gambia but because of poor soils yield only one-third to one-quarter of that grown in the Zaria area. Third, northern Nigeria has a shorter period without a staple crop than has Gambia; rice also stores less well than sorghum. Finally, farmers in northern Nigeria have more opportunities to earn off-farm income than their Gambian counter- 


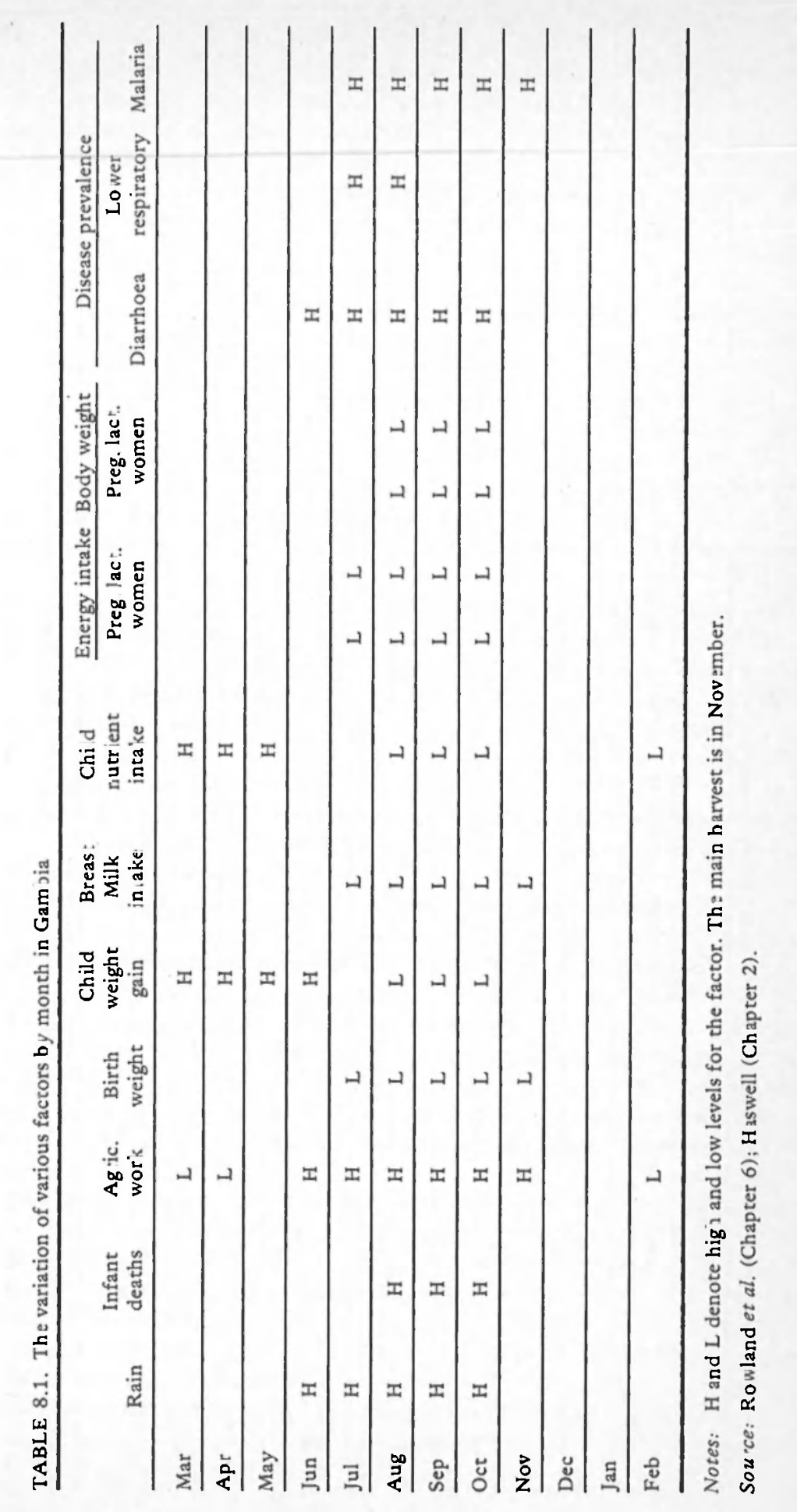




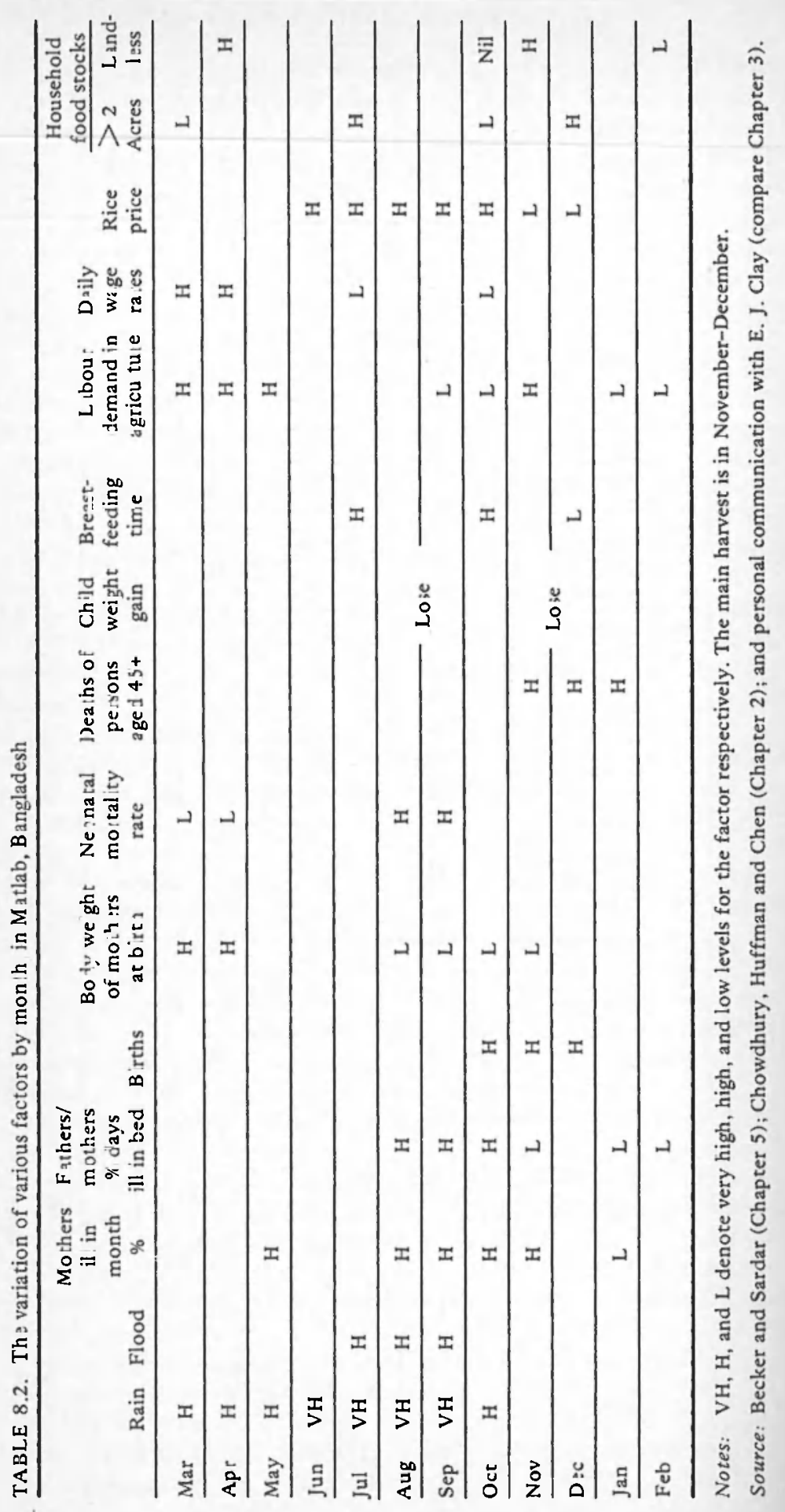


parts. Overall there appears to be greater food availability in northern Nigeria with less of a hungry season than in Gambia, although undoubtedly there are still individuals at risk. Greater poverty and seasonality in Gambia appear to push people into short-term strategies; in northern Nigeria, despite similar problems of labour demand, a better food production position allows more room for manoeuvre.

\section{Qualifications and implications}

While the case-studies confirm that many of the adverse factors initially described do indeed operate together in the wet season, at least in the casestudy areas, three qualifications are in order.

First, care is needed in assessing whether and to what extent seasonality can be regarded as a cause of rural poverty. The conclusion of this book is that seasonality presents contexts which bring poverty to periodic crises. It provides conditions which enable other forces which create and sustain poverty to act more powerfully. There are thus obvious senses in which tropical seasons, as described, help to keep poor people poor. One can even go further and suggest that unimodal seasonality may, other things being equal, provide a context in which exploitation of the poorer by the richer is made easier than in bimodal or non-seasonal climates. Seasonality here is a cause of poverty in the sense that if it were removed, the other forces which create and sustain poverty would be less powerful. Reducing or eliminating adverse seasonal effects would reduce the vulnerability of poor people, and might strengthen their hand. But it would not remove poverty which would continue to be sustained by other stronger forces.

Second, failure of the rains - an irregular occurrence - may be more significant than the regular rhythm of the seasons. We have distinguished two types of process: first, seasonal 'screws'-seasonal cycles with repeated but usually reversible hardship; people are pressed down on a regular basis but the cycle allows some recovery. And second, 'ratchets'-more irreversible effects where disability or misfortune (such as sickness, flood, famine, pregnancy, or death), often linked with erratic climatic occurrences, force a downward shift from which recovery is much more difficult. Seasonal screws have symptoms such as losses of body weight and temporary indebtedness; ratchets, in contrast, most commonly take the form of mortgaging or sales of assets-land, livestock, trees, jewelry, tools, pots and pans, furniture, and future crops and labour. Screws may lead to ratchets; but ratchets are usually provoked by contingencies such as failures of seasons.

Third, seasonal stress and crises vary between different social and economic groups in the same environment. Some may have access to off-farm or nonagricultural employment and income sources which will have smoothing effects on adverse seasonality. Others are affected in different ways by the agricultural cycle. The pre-harvest crisis may sometimes be more acute for self-provisioning small farm families than for landless labourers. The small farm families rely on their harvest for food and income, and may be driven to employ labour at a time when they are very short of money. In contrast, landless labourers who can get work at this time will, if they are remunerated 
Seasonal Dimensions to Rural Poverty

immediately, have a source of food and/or income. For some of them the worst time may be the dry season when there is little work. These examples emphasise the dangers of unsubtle generalisation about seasonality, and the importance of breaking down the analysis not only by environment and by time of year but also by socio-economic group.

Thus far, the main focus of this book has been on analysis rather than policy. But at different points, contributors have pointed to practical implications, and yet others can be derived. Most of these require implementation by government departments or agencies, although non-government agencies also have a part to play. It is sobering, then, to start with a sceptical view of the capacity of government organisations to implement counter-seasonal programmes.

\subsection{Government Perceptions and Responses Ian Carruthers}

\section{Rural sector problems}

Rural development is inherently difficult to sustain because of the many complex and interacting factors that affect agricultural production. These may be categorised as the biological nature of production, the dispersed character and small scale of the production units, their peculiar investment requirements, the traditional set of institutional arrangements, and in some instances, the lack of a well-tested theoretical framework or detailed technical knowledge (Barter, 1962).

The biological nature of the production process is the essence of the seasonality issue. Not only does it create difficulties through the periodic nature of production and work and the long interval between harvests, but these difficulties are added to by climatic irregularities, by insect pests, and by the limited life of the products in storage. These biological rhythms can also change as technical progress creates new opportunities involving new demands for labour or other inputs. For example, in Madhya Pradesh, AprilMay is a slack, dry period and the socially accepted period for marriages. But new agricultural opportunities relating to well irrigation, kharif cropping, weed control and soil conservation are now making this a potentially rewarding work period. One wonders what is the lag between discernment of opportunity and changes in current social customs.

Considerable though seasonal complexities may be, there are still the several other factors to examine. For example, the dispersed nature of production units over varying terrain with a varying resource base makes planning difficult, not least because data are expensive to collect: compare the data problems from an administrator's viewpoint of five fertilizer factories and 500,000 small farmers. The smallness of operations creates other problems too-serving such farmers via an extension service is costly in relation to the value of their production; and they are weak bargainers with government unless there is a collective interest and some form of effective, democratic organisation. Yet further complications arise from institutional factors which include land tenure, credit systems, and marketing arrangements. All play crucial roles in influenc- 
ing the relative success of the various possible patterns of production.

Seasonality, though a prominent factor, is only one dimension among many special problems confronting the rural sector. And such is the complexity of these many dimensions that only an elaborate form of management can hope to succeed in planning and implementing fully comprehensive rural development. It may therefore be useful to turn from general areas of government action to fairly specific dimensions, such as seasonality, where action should be more feasible.

\section{Inter-seasonal variation}

In this book, the main emphasis has been placed upon seasonal rhythms, and the stresses they create. Less emphasis has been placed upon interseasonal variation, although it is this which dominates most farmers' decisionmaking. It is the odd season that frustrates public policies for agricultural credit, buffer stocks, crop storage, public works and so on. It is the problems posed by the 'bad' year that must be solved if regular measures to tackle the more regular seasonal strains are to succeed.

Perhaps the most important prerequisite for coping with the 'bad' year is an early warning system. Whether this should come from a scheme based on local administrators, from remote sensing techniques, or from some combination, is unclear. One valuable practical proposal for an information system to give advance warning of drought is Sandford's (1977) study dealing with drought and livestock in Botswana.

What seems certain is that few governments know at an early enough stage precisely what are the circumstances in their rural areas. Furthermore, few administrations are geared to the flexible action that such information would prompt. However, knowledge of impending disaster is only a necessary condition for avoiding the effects of an extremely poor season. Recent experience in Ethiopia and elsewhere suggests that knowledge is not a sufficient condition to generate feasible avoiding action or preventive measures.

\section{Public sector capacity constraints}

It is conceivable that failure to recognise the special nature and needs of the rural sector accounts for some of the difficulties highlighted in this book. More plausible, perhaps, is that governments lack the capacity to react to the complicated problems presented by agriculture and other activities influenced by the seasons. Even without tackling seasonal variations and needs, governments often face grave difficulties in implementing rural development projects and programmes. An indication of the range of obstacles is given by a Pakistan Government form (code PC-IIIC) for quarterly reporting which lists no less than ninety-five possible bottlenecks.

I am attracted by the ideas of Ilchman (1972) who vividly illustrates the problems of government responding to areas of difficulty such as seasonality by an agricultural analogy. He suggests that the public services in India are like peasant farmers (p. 226):

Given the inputs at their disposal and the margin next to which they live, they are among the most rational allocators in existence-efficient, though not effective; able by one miracle to produce the irreducible 


\section{Seasonal Dimensions to Rural Poverty}

minimum; unable, by any technique of social organisation, to raise the level of output by more than five or ten per cent.

If this is the case, recognition by government of seasonal problems is not an issue, in that there are no major returns to be expected from government action. What is required is rather a massive increase in administrative capacity so that relevant programmes and policies can be effectively devised and implemented. What is required, indeed, is 'an administrative equivalent of the Green Revolution' (Ilchman, 1972).

\subsection{Practical Implications \\ Robert Chambers and Simon Maxwell*}

\section{Counter-seasonal measures}

Seasonal analysis has many practical implications. To what extent 'an administrative equivalent of the green revolution' is needed before they can be followed through is open to debate. Many counter-seasonal measures are already implemented; some rural administrations have a greater capacity than others for implementing them. Administrative capacity itself evolves over time, not least in response to the articulation from below of seasonal demands - for public works, for health services, for agricultural inputs, for credit and so on. The measures outlined below will vary, place by place, in their appropriateness and implementability. They are listed here as a start with a counter-seasonal repertoire from which practitioners can select to match need and opportunity.

\section{A. The timing of administration}

Seasonal analysis has many implications for the timing of activities in government and voluntary agency administration, among which the timing of the financial year is one of the most basic. Two common features may be noted. First, the release of funds for rural projects and programmes is often delayed after the start of the financial year. Second, funds are often exhausted towards the end of the financial year. Thus there may be a regular, seasonal financial famine for some months on either side of the start of the financial year, and, conversely, a regular seasonal period when funds are available. To the extent that this occurs, the question is then whether the availability of funds coincides with the time of greatest need.

In agriculture, health and construction, the timing of need is roughly the same. In all cases, funds are needed in advance of the rains: in agriculture, to enable the timely purchase and supply of inputs and credit before cultivation; in health, to make possible the purchase of drugs and their distribution to rural areas before the rains; in construction, for the purchase and delivery of materials before communications become difficult. There will be other considerations; but to the extent that these points apply, it would seem best if

- Part B of this paper is by Simon Maxwell; the rest is by Robert Chambers, who wishes to acknowledge ideas contributed by the other editors and by many others in discussion and correspondence. 
financial years began well before the main rainy season.

Seasonal labour constraints can be eased by deliberate government action, particularly in adjusting the school term so that children can help at peak periods, as with the cotton harvest in Uganda, rice-cultivation on the Mwea Irrigation Settlement in Kenya, and even potato-picking in rural Britain during the Second World War. Similarly, granting leave to small farmer employees during the agricultural peak seasons can be recommended, especially with employees in tropical tourist industries which have a slack season during the rains.

Tax collection is usually timed for post-harvest periods, and collection at other times might lead to disproportionate hardship. With larger farmers subject to income taxes, there may also be a case for ensuring that their main crop falls within a single accounting period.

Rural campaigns - for adult education, family planning, immunisation, and the like - are often best carried out in dry seasons, for reasons of ease of communication, lack of competing demands from work, and general level of wellbeing and receptivity.

\section{B. The role of public works}

Public works, especially in the off-season, are often cited as a counterseasonal measure to help the poorer people. However, with the possible exception of China and some other socialist countries, public works programmes have fallen far short of expectations in most places where they have been organised (Maxwell, 1978; IBRD, 1976; USAID, 1977). Far from acting as major catalysts of rural development, public works programmes have more often than not degenerated into inefficient and unproductive soup kitchens, costly to organise and supervise. Most important of all, public works programmes have shown themselves to be subject to the same political constraints as underlie much rural poverty, and which have stymied attempts to tackle the problem by other routes; they may even tend to worsen the distribution of asset ownership, with the rich benefiting disproportionately from the type of works undertaken (Grissa, 1973; Sobhan, 1968). The latter point has been made in this book with particular regard to Bangladesh (Chaudhury, Section 3.4), even though public works provide a vast amount of seasonal employment there (Glay, Section 3.5).

Why, then, bother with public works? There are three obvious reasons. One is that 'soup kitchens' in themselves have some value: public works employ people who would otherwise be unemployed. In one area of South India, workers derived 40 per cent of their income from public works (Donovan, 1973), and for some workers in Morocco, the figure was two-thirds (Andriamananjara, 1971). Nevertheless, in his study of public works in Bihar, Rodgers $(1972,1973)$ was able to conclude that in all cases where distribution of consumption was an objective, it was at least partly successful'.

A second reason why it may be worth bothering with public works is that opportunities exist to make them more productive (Lewis, 1972; WFP, 1976b). For example, one study indicates that the provision of spades and wheelbarrows on public works in India increased output by between 30 and 100 per cent (Costa, 1973). Other observers have stressed the value of higher wages and piece work (IBRD, 1976), or the value of agrarian reform as an in- 


\section{Seasonal Dimensions to Rural Poverty}

centive (Tiano, 1972). Greater benefits could also be obtained from the assets created if complementary inputs were provided and if maintenance were bet ter; 'greater production is not guaranteed by the earthworks themselves' (WFP, 1976a). It is necessary to match irrigation facilities with better seeds and more fertilizer, and also to set up a reliable maintenance system which will keep the channels open.

A third reason for not discarding public works programmes is that, despite poor productivity and political limitations, they do manage to create a certain amount of long-term employment. How much employment varies greatly from country to country, though, and from project to project. The permanent employment created tends to be less on works which are highly labour-using in construction than on those which are not, so that the long-term and short-term objectives are to a certain extent in conflict (IBRD, 1976). This contrast is one reason behind the general disapproval in the public works literature of road construction projects which meet the short-term objective of employing large numbers of people, but are seen to have little long-term impact (UN, 1975; IBRD, 1976).

In considering the contribution that public works might make to the easing of seasonal problems, it is important to look, not simply at the employment created, but at the assets produced. A part-and sometimes a large part-of the seasonal problems faced by a community may be of a kind that public works are well suited to tackle: flooded roads making it difficult to bring food into a village; poor drainage and sanitation encouraging the breeding of mosquitoes and flies in the rainy season; price fluctuations and food shortages due to lack of storage facilities. There is also obvious scope for closer complementarity between different works schemes, and for closer integration between schemes planned and carried out at the village level (often with a large voluntary contribution) and those organised at higher levels in the administrative hierarchy.

To the extent that an awareness of the seasonal dimension suggests action at the community level, it may be possible to avoid some of the conflicts of interest which bedevil public works schemes. This is a hypothesis which requires testing, since it is likely that someone always benefits from disaster, but prima facie, public works aimed at lifting particular seasonal constraints which affect everybody seem well placed to attract support from the community as a whole and to benefit everybody equally. The control of mosquitoes might seem a candidate for projects of this sort, and there must be other examples. The point is that the basic needs planner may find in seasonality a path to the avoidance of conflicts (Maxwell, 1978).

Where conflicts or political problems relating to the assets being created cannot be avoided, it may be necessary to focus more simply on the employment created. Here a crucial problem arises: seasonal poverty is the result of lack of income at particular times of year, and public works provide incomes, but the two are not necessarily at the same time. Seasonal hunger is not at its worst during the slack season in agriculture, but at the time when the land is being ploughed and planted before a new harvest, when every available man and woman is busy in the fields. To the extent that the public works literature discusses seasonality at all, it assumes that poverty and unemployment are 


\section{Conclusions and Practical Implications}

temporally co-existent. But if public works provide incomes at a time when they are less urgently needed, then the problem of savings and storage arises, which involves questions of institutions, the role of money-lenders, and control over markets. Public works in January do not guarantee that saving will take place to meet consumption needs in July. Public works projects may therefore need to be treated as an integral part of a wider attack on the problems of seasonality.

Finally, however, if public works are able to help lift seasonal constraints, then it may be that their value has been underrated in the literature. Most cost-benefit analyses fail to count as a benefit the consumption of the labourers during the construction period, the exception being Rodgers (1972). If, however, such aspects of poverty as malnutrition and child mortality are heavily influenced by seasonality, and if public works projects are able to tide families over the hungry season, then the value of works is not to be measured simply in terms of short-term consumption, but in the longer term as improved health, productivity, receptivity to education, and so on. The weight given to consumption by public works participants, to take only one aspect, could vary according to the month in which public works take place.

Such refinements require more empirical data. It is by no means clear that the poor track record of public works can be remedied, nor that the seasonal problem is particularly amenable to solutions which include public works. But to be realistic does not preclude being optimistic: public works are a flexible tool and with the right political support can be extremely powerful. As the seasonal dimension becomes better understood, public works certainly deserve to be kept in mind.

\section{Agriculture, food and nutrition}

There are many ways in which farming systems can be adapted and developed to reduce adverse seasonality. One approach is to introduce techniques which make lower energy demands at peak periods, though a danger here is that employment and incomes for the landless may be reduced. Another is to develop sequences and mixes of land preparation and crops (minimum tillage, inter-cropping, serial cropping, fodder crops such as the tree legume Leucaena (NAS, 1977), etc.) which reduce risks and spread both labour demands and flows of food and income from harvests. In particular, short-duration food crops such as quick-maturing millets, even if not high-yielding, can help by giving farming families a food supply before the main harvest. Nor should cash crops be unthinkingly condemned as they sometimes are; they may, more often than not, give families reserves of cash and of purchased food which they could not have obtained with food crops on the same land. Livestock, too, can have important smoothing and buffering effects, providing milk, meat or cash at otherwise lean times. Smallstock (sheep, goats, pigs, ducks, hens, etc.) are often important buffers against hunger and permanent impoverishment. The main point is that the farming system should be seen in terms of family livelihoods and food security round the whole year, and modified where possible to improve these, with especial attention to the most difficult times.

Irrigation increases productivity, reduces risk and increases employment in ways that are very well known; it also contributes greatly to the productivity of 
Seasonal Dimensions to Rural Poverty

the seed-fertilizer combinations of the green revolution. Less well recognised is its value to families, whether small-farming or landless, in spacing food and income flows round the year. Irrigation may lift families above the thresholds of adequate livelihoods by filling in an annual trough of lack of food and income. Where it generates employment all round the year it may also attract families for permanent quasi-urban settlement in rural areas (Chambers and Harriss, 1977). Where irrigation is not possible, techniques of water harvesting such as contour ridging and ploughing to reduce run-off losses, and dryland farming methods which conserve soil moisture (Arnon, 1972; NAS, 1974), may have similar if less dramatic effects. But of all the counter-seasonal strategies which do not involve a redistribution of the means of production, irrigation is probably the most powerful.

In the improvement of nutrition, timing appears to be crucial in policy design. Feeding programmes-the most direct form of intervention-may well reduce body weight loss if administered at any time of the year. There may, however, be some times of the year when they will be more effective than others. For example, fewer leakages of food to uses other than consumption may occur in the wet season. Optimal timing for a food-for-work programme may depend on balancing considerations such as the availability of labour (in slack seasons) against the need of poor families for calories (at times when they have other work). Such programmes may also shield families from the ratchet effects of unforeseen contingencies if they contribute to food supplies at the most vulnerable times of year. A balance of considerations also applies with strategies to reduce the energy expenditure of farm families. One way of improving their nutritional security is to reduce the energy required when energy demand is high and food supply is low. Such a strategy may reduce human energy expenditure through mechanisation, chemical weed control, or even the introduction of varieties for which operations are less time-constrained. But care has to be taken in assessing who gains and who benefits. If all are small farmers, then all may gain. But if there are poorer people who need to sell their labour, innovations of this sort may deprive them of their livelihoods. As with other counter-seasonal strategies, account has to be taken of local conditions and of the interest of different groups.

\section{Storage and savings}

To even out the seasonality of food supply, many storage techniques can be used: crops may be grown which store well in the soil, such as cassava (manioc); fruits, vegetables, fish and meat may be dried in the sun; fish and some vegetables can be salted; and most commonly crops are stored in silos, bins, and family grain stores.

Studies of on-farm grain storage in Africa and Asia have shown that traditional technology can be very efficient. In Andhra Pradesh, a careful study found losses of only about 4 per cent in farm-level paddy stores (Boxall et al., 1978) and village-level post-harvest losses in rice in Bangladesh have been found to be only 5-8 per cent (Greeley, 1980), far less than earlier estimates (under a variety of definitions) ranging from 10 per cent to 38 per cent ( $i b i d$ ).

Improvements are nonetheless possible. Despite the low losses in storage in Andhra Pradesh, there are still high rates of return on improvements to tradi- 
tional stores. (Boxall et al., 1978). The deterioration of grain in storage is often not due to deficient technology but to poor maintenance and poor hygiene. Before newly harvested grain is placed in a store, it should be cleaned, and cracks in the walls filled in with mud plaster to prevent reinfestation through the eggs and larvae of insect pests. A problem here is that cleaning and maintenance are required when stores are empty which may be just when people are busy in the fields. Absence on migration may also hinder construction of necessary new storage capacity (Section 7.5). In some communities it might be worth devising programmes which would encourage people to spend more time working on their own household storage facilities, perhaps compensating them in some way for wages lost by not participating in public works or migratory employment.

Government purchases of grain can reduce seasonal hardship by maintaining prices at harvest, and then through releases of grain on the market at times of shortage, by keeping prices down. This requires the maintenance of adequate buffer stocks in official storage. The issues of government intervention, procurement, pricing, storage, and subsidy are not simple (Harriss, 1977, 1978) and perverse outcomes can occur. It is enough to note here that if the desired effects can be achieved-maintaining floor prices at harvest, and restraining price rises in the lean season - the poorer people will benefit disproportionately. At harvest, small farmers and sharecroppers who have to repay loans in cash will benefit because they will get more for their crop; and in the lean season, all those-landless labourers and small farmers alike - who are short of food will benefit through having to pay less for it. An even stronger counterseasonal strategy is to provide free or subsidised food to the poorer people all round the year, as practised in Sri Lanka with the rice ration and other food subsidies, and in Kerala through the fair price shops which, exceptionally for India, are found throughout the rural areas. The very high life expectancies and low fertility of Sri Lanka and Kerala are usually attributed to education, health services, and late marriage. It is at least possible that a major factor is the exceptional food security of poor families in those two regions.

Village savings clubs or cooperatives may provide a form of storage without wastage. In one African country, village savings clubs have been particularly effective in enabling poor farmers to buy fertilizer and to obtain it in bulk at a reduced price (Oxfam, 1975). In West Bengal, a system called dharmagola helps landless labourers and poor farmers. They deposit what they can in grain or cash at good times, and are then allowed to withdraw twice that amount in lean times, repaying again at the next good time. In tackling seasonal deprivation and dependence, perhaps especially in Asia and West Africa, consumption credit for the lean season appears a high priority.

\section{E. The family, women and children}

The experience of poverty is both shared and distributed within families. All suffer, but some suffer more than others. Each case deserves to be examined in its own right, but privation is often especially experienced by women; and Chapter 6 suggests that a symptom of extreme poverty is the way children have to be neglected as parents struggle to secure future food supplies for the family. Much evidence can be adduced of the seasonal stress on women and 
children in particular. In thinking about policies for food production and health services, family welfare is a central consideration, not so much in immediate action as in ultimate goals. Programmes which concentrate action on child welfare and disregard all else are usually treating symptoms rather than causes, and may even do harm by distracting women from essential production activities. Even more serious, however, are programmes for improved food production which do not consider the problems of women and children at all, and which damage the welfare of families by imposing excessive burdens on women. Palmer (Section 7.2) has made the point that agricultural planners habitually forget the effect on women of the 'green revolutions' they organise.

One important goal is to lighten the disproportionate work burdens that fall on women, especially during times of peak labour demand. Palmer discusses various possibilities in Chapter 7, and others have suggested 'equity-oriented technologies' which reduce the work of women (or of the poor generally) and which are not likely to have the benefits captured by the better-off (Oxfam, 1976). Examples are improved water supplies which relieve women of long journeys carrying water, and improved hoes which reduce the energy used in weeding (Section 2.6), and techniques to reduce the drudgery of food processing, such as peeling cassava, pounding yams and grinding millet.

If such innovations apply to unpaid tasks, they may not deprive women or others of income. The danger often is that innovations transfer traditional women's work to machines, men and urban factory workers. For example, the livelihoods of very poor rural women in Bangladesh who have relied for much of their income on laborious foot-pounding to husk rice, or who have been employed in manual threshing, are threatened by power hullers for husking and by new threshing machines. Some of these changes appear unavoidable. What is vital is to see what seasonal sources of income they remove from whom, and to seek to provide alternatives. This may be especially important where women earn money at times when their husbands are seasonally unemployed, and where women's earnings, as seems often the case, are spent more responsibly on family needs than those of men.

Small families, and especially female-headed households where the male has deserted or is a migrant, are especially vulnerable. Seasonal conflict between agricultural activities and child care is most acute in these small families and there is less family labour to deal with contingencies. Agricultural research and extension are almost invariably directed towards families which are stronger and which command more resources. Measures to be recommended here include careful analysis of the activities and constraints of small and weak families, the development of innovations designed for them, and agricultural extension services specifically for women (Pacey, 1978).

Child care facilities in seasons of stress may be arranged to ease the seasonal burden on families and risks to children. Two possible measures are the provision of day-care in villages during periods of peak labour demand in the fields, and the provision of food for the most vulnerable groups at times of food shortage. These two measures may be linked since the season when day-care is most needed is usually also the time when food is most short and when children are most likely to have been recently weaned. The day-care facility may thus be a suitable location for seasonal child-feeding. 
One final and much more problematic factor on which action may possibly be considered to ease the seasonal stress for women concerns the timing of pregnancy and birth. The conjunction often observed of late pregnancy and birth with periods of peak labour demand, food shortage, and high exposure to infection appear bad, linked as it is to low birthweights, high neonatal mortality, and poor prognoses for babies (Chapter 6). But the notion of family planning aimed at an optimum season of birth seems nowhere to have been adopted in modern societies. There are dangers of oversimplifying here; and Schofield has shown how complex are the pros and cons of different seasons of birth for the prospects for the first two years of life (Schofield, 1974). Experience of the acute seasonal stress in late pregnancy in Gambia has led Rowland $e t$ al. (Section 6.2) to suggest that seasonal birth regulation aimed at avoiding births during the rains might be of some value. Elsewhere, without prejudging whether or when there might be an optimal time for birth, this question, raised with rural women, might provide a good point of entry for discussions about family planning. Rural women may have well-founded views about the best time to give birth, in which case a discussion of this could lead logically into questions of how to time and control conceptions.

\section{F. Heallh services}

The importance of seasonality seems to have been largely lost sight of in the planning of modern health services. Attention has concentrated on location rather than timing. Seasonality is recognised mainly in terms of constraints: when rains come and roads become impassable, villages served by mobile clinics are cut off, and mass immunisation programmes in rural areas may have to be suspended (Tomkins, Section 6.4). The costs of sickness - in terms of losses of family food and income, of losses of body weight reserves, and of national agricultural production foregone-are both high and very seasonal. Sickness in an agricultural slack season entails suffering; but its social and economic costs may be far less than those of sickness in an agricultural season which directly prevents work to earn income or grow food. There are arguments, on both welfare and economic grounds, for special attention to health care during the agricultural seasons, and to those diseases and complaints which are most likely to incapacitate at that time (Chambers, 1979). There is here a strong but little recognised complementarity between health services and agriculture.

Six measures can be proposed:

(1) seasonal stocking of rural clinics. It is rare for rural clinics and health posts to be stocked with medicaments to meet seasonal needs. This is, however, a need where disease is seasonal and where clinics are cut off during rains and floods.

(2) preventive and curative priority for diseases of the wet (and agricultural) seasons. This applies especially, depending on local conditions, to the diarrhoeas, malaria, skin infections, guinea-worm disease, and dengue fever. It also applies to whatever diseases and complaints most incapacitate and weaken at these periods of peak agricultural activity. Malaria is a notable case where much may sometimes be achieved for low cost and with enthusiastic public support. An example is seasonal anti-malarial 
Seasonal Dimensions to Rural Poverty

chemoprophylaxis combined with other preventive measures in Raigarh District, Madhya Pradesh, where in two years an incidence believed to have been about 95 per cent was brought down to almost nil, with poor people prepared to pay for their pills (Sister Lorraine Ryan, personal communication). The cost-effectiveness of chemoprophylactic antimalarial programmes can also be increased by shifting from year-round to seasonal implementation, as in some parts of Mozambique where action is being concentrated on the seasons of highest incidence (Malcolm Segall, personal communication).

(3) locating health services according to seasonal needs. A case can be made for concentrating health services in those areas where the incidence and cost of sickness in the wet and agricultural seasons are highest.

(4) caution in introducing mobile clinics. Mobile clinics have been questioned on other grounds. The additional seasonal argument is that they may be unable to reach the more remote people who are often poorer and more vulnerable to adverse seasonality; and that during the rains, when health services are most needed in less accessible places, mobile clinics will be at their least mobile, often confined to tarmac roads, if not to garages.

(5) seasonal staffing. This involves the timing of leave, or shifting staff from one area to another to ensure high coverage at the times of greatest need. This may, however, be a difficult refinement to implement. It has been tried in Matlab thana in Bangladesh, for which Chen et al. (1979, p. 186) report that

... the annual epidemic of diarrhoeal diseases . . places enormous stress on the Matlab health care delivery system for three months of the year. To meet such stress, shift of facilities and staff may be required. Preventive work and nonseasonal curative services such as family planning, may be deferred to slack seasons, so that resources can be focused to meet peak service demands. It should be pointed out, however, that this increase of staff efficiency may be achieved only at the cost of increased program complexity. Shifting of staff requires more training, supervision, and other program support services.

(6) selecting community health workers who do not have farming obligations. There is a danger that primary health care workers in villages will themselves be farmers or have farming obligations, and will be distracted from health work at the times of greatest need. Seasond analysis leans here against that conventional wisdom which holds that community health workers should be part-time farmers, typical members of the community, and unpaid. If a community faces a seasonal crisis simultaneously in cultivation and in health, a community health worker in a farming family will be torn between conflicting obligations, and those of cultivation for the family may prevail over those of health for the community. In planning primary health care, and in selecting community health workers, this is a factor to be borne in mind.

\section{G. Seasonal analysis and action}

As noted in the introduction, the perceptions of urban-based professionals are distorted by biases so that they either underestimate or fail to recognise 
seasonal linkages and seasonal deprivation. This failure of perception presents an opportunity. It is precisely because seasonality has so often been missed as a link between health, agriculture, nutrition and poverty, that there is so much scope for counter-seasonal programmes and measures such as those outlined above.

One major problem is identifying the types of counter-seasonal programme appropriate for each environment. This can be approached in two complementary ways.

The first, top-down, approach involves seasonal mapping. At an early stage in planning counter-seasonal strategies, this means mapping the spatial and seasonal distribution of adverse factors and their linkages. What can be done will depend on what data and knowledge are available. At the very least, maps indicating the agricultural peak seasons and the seasonal incidence of rural diseases could be matched and analysed to identify zones of adverse healthagricultural linkages. This could be deepened with other data - on seasonal births, deaths, body weights, malnutrition, wage rates, indebtedness and food prices - as available. Any such approach should quite quickly point to certain zones deserving closer analysis at certain seasons.

The second, bottom-up, approach, would rely heavily on local knowledge. Official statistics are often misleading, and need correction at the lowest level, implying decentralisation. One approach is a required procedure for locallevel staff to carry out seasonal analysis. Health and agricultural staff can be required jointly with each other and with rural people to identify seasonal linkages between health, nutrition, agriculture and poverty and in the areas where they work. Particular attention might be paid to the views and experience of those poorer rural people most adversely affected. The incentives to staff can be enhanced by workshops with their colleagues from other areas to which their findings are reported, and then by together working out and agreeing proposals for action. Such joint analysis and action can be suggested for the district and subdistrict level. This procedure should heighten awareness of seasonal problems leading to health programmes and other interventions better geared to the seasonal needs of agriculture and of the poorer people.

But implementation, as argued by Carruthers (Section 8.2), is the crux. Good ideas which are not implementable are bad ideas, at least for the time being. The best way forward may be to develop methods of seasonal analysis and a repertoire of interventions which are simple, manageable, replicable and effective, and which involve rural people as partners. Analysis is the easier part; the greater challenge is action. Ways forward may be sought through combinations of decentralised seasonal analysis, action programmes, evaluation, and then training and replication. Such measures might restrain processes of impoverishment, increase agricultural production, and benefit those who are poorer and weaker. This might be achieved, moreover, without significant loss, and often with gains, to those rural people who are less poor and more powerful. The local political obstacles which so often impede and subvert programmes intended to benefit the rural poor should therefore be less serious than usual, and may not appear at all. Seasonal analysis and action should, then, benefit those most in need, making things better for them at the times they find worst. 
Seasonal Dimensions to Rural Poverty

\section{Conclusion}

This book has been mostly concerned with trying to understand in factual terms what seasonal influences bear most strongly on the welfare of poor rural people in tropical countries. Many of the papers have, however, followed through to practical implications, and this chapter has illustrated how seasonal analysis can stimulate interdisciplinary thought about the choice, design and above all timing of rural development activities. For the practitioner Table 8.3 provides a checklist of policy implications that have been discussed in the text.

Seasonal analysis and measures to relieve seasonal problems do not require complex or large-scale research. What they do require is an interchange of knowledge and ideas between rural people, doctors, agriculturists, social scientists, planners, administrators, and politicians. Since each environment is in some respects unique, it requires that this analysis and exchange of ideas occur at the local level. Each type of environment will require its own mix of measures and its own priorities. In one place, tackling a disease which has a crippling effect in the wet season may be a higher priority than modifying farming systems; in another, changing farm technology of the farming calendar to enable smaller poorer farmers to obtain an earlier food crop, or higher yields, may be more important. But in all environments, there are likely to be seasonal links between health, nutrition, agriculture and poverty which, when examined, will suggest new programmes or new timing and emphases in existing programmes.

The benefits from this approach may be especially high where the poorer rural people are able to sustain an adequate livelihood for most of the year, but are highly vulnerable or unable to support themselves during a lean period. If a government objective is the provision of basic needs and an adequate livelihood to all citizens, then a focus on the lean period may often have higher returns in terms of livelihoods created-helping many people over the threshold - than attempts to create fewer entirely new livelihoods around the year. Complementary or alternative to this approach is raising food and income floors at other times and improving savings and storage in order to enable the poorer rural people to tide over the lean periods. Off-farm employment, whether through migration, public works, small-scale industries, or other means, is a major source of smoothing and may have to be a more prominent component in future counter-seasonal strategies to secure adequate livelihoods.

In recommending seasonal analysis and counter-seasonal programmes, three reservations must be made.

First, rural poverty has international aspects. The temptation is to conclude, from a seasonal analysis, that the measures needed are only internal to third world countries. This is not so. Rural poverty is linked with unequal exchange between rich and poor countries, to commodity prices, and to other concerns of the North-South dialogue. The seasonal mode of analysis should not divert attention from these international aspects but should rather, by exposing more of the scale, nature and dynamics of rural poverty, show up even more clearly the relevance of international action to redress the inequalities of trade and economic relations. 
TABLE 8.3. Checklist on the policy implications of seasonality

Sections in this book where discussed

Government technical services

(1) long-range weather forecasting

8.2

(2) monitoring drought/food situation

8.2

(3) agricultural services for food crops

Government social policies

(5) social education in the off-season

Government food policy

(6) maintenance of buffer food stocks

8.3

(7) food price regulation/market intervention

(8) decentralise food stores to vulnerable areas

(9) timing of tax demands

(10) timing of end of financial year

8.3

(11) timing of school and other holidays

Seasonal employment

(12) careful and selective use of public works

(13) small-scale industry in rural areas

8.3, 3.5,

3.4

Women's employment

(14) fuller recognition in agricultural planning

$7.1,7.2$

(15) tools and techniques to relieve drudgery (water supply, hand tools) $2.6,7.2,8.3$

(16) agricultural services for women

8.3

(17) day-care facilities for children

$7.2,8.3$

Family welfare

(18) seasonal food supplies for vulnerable groups

8.3

(19) explore seasonal birth regulation

$6.2,8.3$

Health services

(20) plan for diseases with critical seasonal peaks (malaria? guinea-worm?)

(21) regulation of staff leave, drug issues

(22) concentration on seasonally vulnerable people

(23) timing of health education work

$6.5,8.3,2.5$

8.3

8.3

$2.5,8.3$

Agriculture

(24) use of irrigation to extend growing season

$2.1,2.6,8.3$

(25) use of dryland farming methods

(26) technology to reduce labour peaks

8.3

2.6

7.3

(27) inter-cropping as a safeguard against climatic variability

(28) effect of new crop varieties

3.5

(29) crop breeding for drought resistance

(30) village savings clubs

Crop storage

(31) construction of food stores

(32) operation of family grain stores

$7.3,8.3$

(33) crops that store in the soil (cassava)

8.3

(34) need for milk/cheese/butter storage

$3.3,6.6$ 


\section{Seasonal Dimensions to Rural Poverty}

Second, the question - who benefits? - must always be asked. We have argued that counter-seasonal measures may differentially benefit the poorer rural people. But the extent to which this is so depends on the nature of the programme and the local social and political structure. Seasonal supplies of drugs may be available only to those who are more influential. Public works may create facilities for the richer farmers. The effects of relief food vary: the famine of 1972 in the highlands of Papua New Guinea was relieved by moving food into the area; but in 1974 food was moved into Assam and West Bengal and the famine there was not relieved. Papua New Guinea had a relatively undifferentiated social hierarchy, so that all had access to the food; whereas in Assam and West Bengal, the local hierarchy enabled those who were powerful to benefit while the poorer people did not, or benefited much less. Counterseasonal programmes can, as in this example, be subverted. But more generally they may benefit the poor precisely because the powerful have less need of them and less to gain from them.

Finally, seasonal analysis should not divert attention from more basic issues. Those who are less poor are much less vulnerable to seasonal afflictions and stress. The most effective counter-seasonal measure is to remove extreme poverty, and this could often best be done by redistributing land and water. Where such reform is not yet feasible, other counter-seasonal measures may appear palliatives or diversions. But this need not be so. We have seen the close links between seasonality, poverty and dependence. If counter-seasonal programmes can enable the poorer rural people to gain more adequate flows of food and income and to become less vulnerable and less dependent, they may then be more able and ready to assert themselves. More food and better health may provide the physical and psychological preconditions for political organisation and pressure to achieve reforms. If, after such reforms, the poorer families have direct control of adequate means of production, and if they receive adequate returns for their labour, they will then be much less vulnerable to adverse seasonal effects. Seasonally-oriented programmes will still be needed; but the need will be less acute.

\subsection{References}

Andriamananjara, R. (1971), Labour Mobilization: the Moroccan Experience, Discussion Paper No. 15, Centre for Research on Economic Development, University of Michigan.

Arnon, I. (1972), Crop Production in Dry Regions, 2 vols., London, Leonard Hill.

Barrell, R.A.E., and Rowland, M.G.M. (1979), 'Infant Foods as a Potential Source of Diarrhoeal Illness in Rural West Africa', Transactions of the Royal Sociely of Tropical Medicine and Hygiene, 73, 1, pp. 85-90.

Barter, P.G.H. (1962), 'Special Problems of Agricultural Planning', Monthly Bulletins of Agricullural Economics and Statistics, 2, 6.

Boxall, R. A., Greeley, M., and Tyagi, D. S., with Lipton, M., and Neelakanta, J. (1978), 'The Prevention of Farm-level Food Grain Storage Losses in India: a Social Costbenefit Analysis', IDS Research Report, Institute of Development Studies, University of Sussex (October).

Chambers, Robert (1979), 'Health, Agriculture and Rural Poverty: Why Seasons Matter', IDS Discussion Paper No. 148, Institute of Development Studies, University of Sussex (December). 
Chambers, Robert, and Harriss, John (1977), 'Comparing Twelve South Indian Villages: in Search of Practical Theory', in Green Revolution? Technology and Change in Rice-Growing Areas of Tamil Nadu and Sri Lanka, ed. B. H. Farmer, London and Basingstoke, Macmillan.

Chen, Lincoln C., Alauddin Chowdhury, A.K.M., and Huffman, Sandra L. (1979), 'Seasonal Dimensions of Energy Protein Malnutrition in Rural Bangladesh: the Role of Agriculture, Dietary Practices, and Infection', Ecology of Food and Nutrition, 8, pp. 175-87.

Costa, E. (1973), 'Maximising Employment in Labour-intensive Development Programmes', International Labour Review, 108, p. 5

Donovan, W. G. (1973), Rural Works and Employment: Description and Preliminary Analysis of a Land Army Project in Mysore State, India, Occasional Paper No. 60, New York, Department of Agricultural Economics, Cornell University.

Elliott, K. (1975), The Training of Auxiliaries in Heallh Care (an Annotated Bibliography with Project Descriptions), London, Intermediate Technology Publications

Godbole, A. (1973), 'Productive Relief Works for the Rich', EPW, 8, 17 (28 April).

Greeley, Martin (1980), 'Rural Technology, Rural Institutions and the Rural Poorest', Discussion Paper, Institute of Development Studies, University of Sussex.

Grissa, A. (1973), Agricultural Policies and Employment: Case Study of Tunisia, OECD Development Centre Studies, Employment Series, No. 9, Paris, OECD.

Harriss, Barbara (1977), Piecemeal Planning in Rice Markets: the Effects of Partial Government Intervention on Marketing Efficiency in a South Indian District, Monographs in Development Studies No. 1, School of Development Studies, University of East Anglia.

Harriss, Barbara (1978), 'Allocation, Location and Dislocation in Non-market Rice Distribution', Journal of Development Studies, 15 (1) (October), pp. 87-105.

IBRD (1976), Public Works Programmes in Developing Countries: a Comparative Analysis, World Bank Staff Working Paper No. 224, Washington, IBRD.

Ilchman, W. F. (1972), 'Decision Rules and Decision Roles', African Review, 2 (2), pp. 219-46.

Lewis, J. P. (1972), 'The Public Works to Low-end Poverty Problems', J. Development Planning, No. 5.

Lewis, J. P. (1975), 'Designing the Public Works Mode of Anti-poverty Policy', Princeton University, Brookings Institute (mimeo).

Malawi (1973), A Guide to the Safe Storage of Cereals, Oilseeds and Pulses, Lilongwe (Malawi), Extension Aids Branch, Ministry of Agriculture.

Maxwell, S. (1978), 'Food Aid, Food for Work, and Public Works', Discussion Paper No. 127, Institute of Development Studies, University of Sussex.

NAS (1974), More Water for Arid Lands, Washington, National Academy of Sciences.

NAS (1977), Leucaena: Promising Forage and Tree Crop for the Tropics, Washington, National Academy of Sciences.

NIAE (1974), Botswana Dryland Farming Project, Wrest Park, Bedfordshire, National Institute of Agricultural Engineering.

Oxfam (1975), Saveway Clubs, Oxford, Oxfam (booklet and kit)

Oxfam (1976), Field Directors' Handbook, Oxford, Oxfam. (See especially Sections 4, 18, 19 and $34 ; 1976 \mathrm{ed}$. only).

Pacey, A. (1978), Gardening for Better Nutrition, London, Intermediate Technology Publications.

Rodgers, G. B. (1972), Poverty and Policy: the Impact of Rural Public Works in the Kosi Area of Bihar, India, Unpublished D. Phil. thesis, University of Sussex.

Rodgers, G. B. (1973), 'Effects of Public Works on Rural Poverty', EPIW, Annual Number, 8, (4-6), Bombay (February).

Ruttan, V. W. (1977), 'Induced Innovation and Agricultural Development', Food Policy, 2 (1), Pp. 196-296.

Sandford, S. (1977), Report to UK Ministry of Overseas Development (May).

Schofield, Susan (1974), 'Seasonal Factors Affecting Nutrition in Different Age Groups and Especially Pre-school Children', Journal of Development Studies, 11 (1), pp. 22-40.

Sobhan, R. (1968), Basic Democracies, Works Programmes and Rural Development in East Pakisian, Dacca, Oxford University Press.

Stevens, C. (1977), The Uses of Food Aid in Lesotho, ODI Working Paper No. 4, 
Seasonal Dimensions to Rural Poverty

London, Overseas Development Institute (mimeo).

Tiano, A. (1972), 'Human Resources, Investment and Employment Policy in the Maghreb', International Labour Review, 105 (2)

UN (1975), Poverty, Unemployment and Development Policy, New York, UN/ST/ESA/29.

USAID (1977), Creating Rural Employment: a Manual for Organising Rural Works Programmes J. W. Thomas and R. M. Hook, Washington.

Warrell, David, and Arnett, Charles (1976), 'The Importance of Bites by the Saw-scaled or Carpet Viper (Echis Carinatus): Epidemiological Studies in Nigeria and a Review of the World Literature', Acta Tropica, 33, 4.

WFP (1976a), Interim Evaluation Report Bangladesh 2197 Q. Relief Works Programme for Land and Water Development, Rome, WFP/CFA 2/12-A Add C23.

WFP (1976b), The World Food Programme and Employment Report, by the Executive Director, Rome, WFP/CFA: 1/15-A.

Whitehead, R. G., Rowland, M.G.M., Hutton, Melanie, Prentice, A. M., Muller, Elisabeth, and Paul, Alison (1978), 'Factors Influencing Lactation Performance in Rural Gambian Mothers', Lancet, 22 July, pp. 178-81.

World Bank (1975), Rural Development Sector Policy Paper, Washington, World Bank. 